\title{
Comparison of Inorganic Carbon System Parameters Measured in the Atlantic Ocean from 1990 to 1998 and Recommended Adjustments
}

\author{
Rik Wanninkhof, ${ }^{1}$ Tsung-Hung Peng, ${ }^{1}$ Betty Huss, ${ }^{1}$ Christopher L. Sabine, ${ }^{2}$ Kitack Lee ${ }^{3}$ \\ ${ }^{1}$ NOAA, Atlantic Oceanographic and Meteorological Laboratory, Miami, Florida \\ ${ }^{2}$ NOAA, Pacific Marine Environmental Laboratory, Seattle, Washington \\ ${ }^{3}$ Pohang University of Science and Technology, Republic of Korea \\ Additional Contributors (arranged alphabetically): \\ Kumiko Azetsu-Scott, John L. Bullister, Richard A. Feely, Mario Hoppema, Peter Jones, \\ Robert M. Key, Alex Kozyr, Frank J. Millero, and Aida F. Ríos
}

Prepared by

Alex Kozyr

Carbon Dioxide Information Analysis Center

Oak Ridge National Laboratory

Oak Ridge, Tennessee, U.S.A.

Date Published: May 2003

Prepared for the

Climate Change Research Division

Office of Biological and Environmental Research

U.S. Department of Energy

Budget Activity Numbers KP 1204010 and KP 1202030

Prepared by the

Carbon Dioxide Information Analysis Center

OAK RIDGE NATIONAL LABORATORY

Oak Ridge, Tennessee 37831-6335

managed by

UT-Battelle, LLC

for the

U.S. DEPARTMENT OF ENERGY

under contract DE-AC05-00OR22725 



\section{CONTENTS}

Page

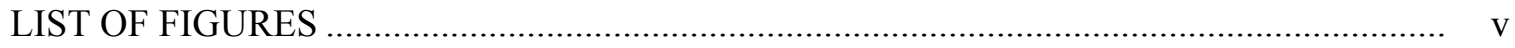

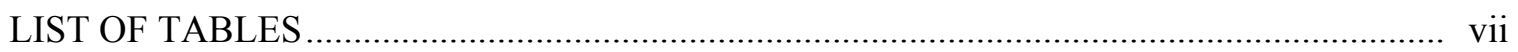

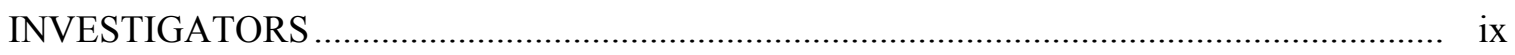

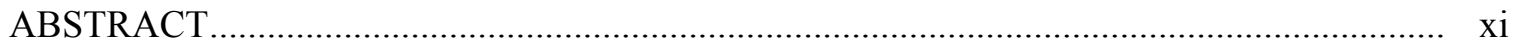

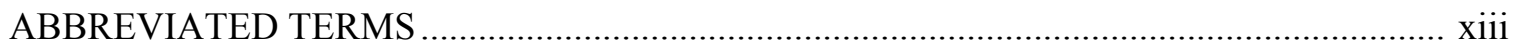

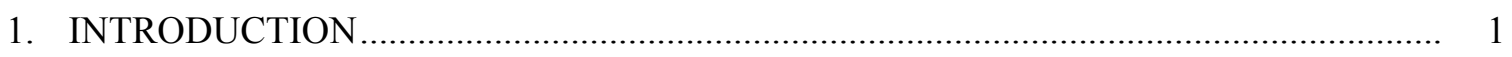

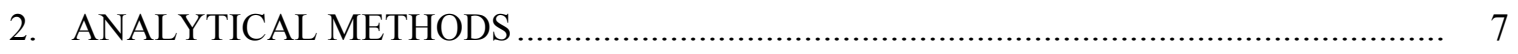

3. PROCEDURES TO DETERMINE OFFSETS ........................................................... 9

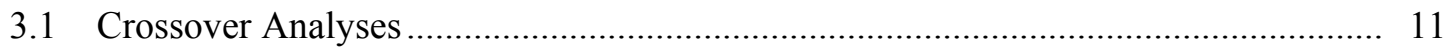

3.2 The Regional Multiple-Parameter Linear Regression Method for Checking for Offsets in DIC and TAlk ............................................................. 12

3.3 The Multiple-Parameter Linear Regression Method for Checking

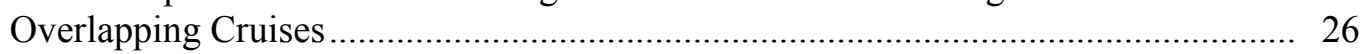

3.4 Other Inorganic Carbon System Parameters ......................................................... 26

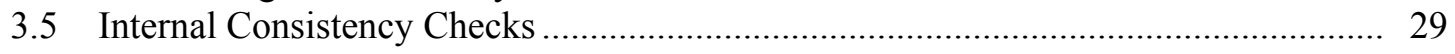

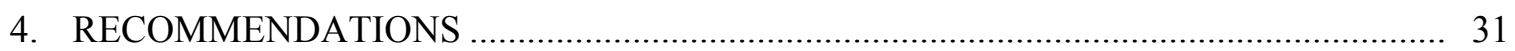

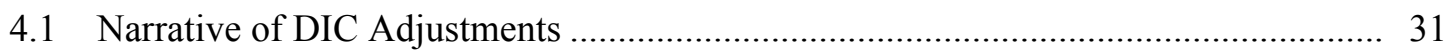

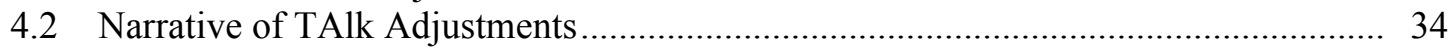

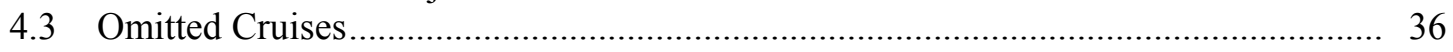

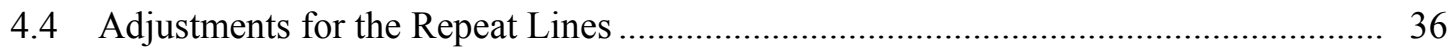

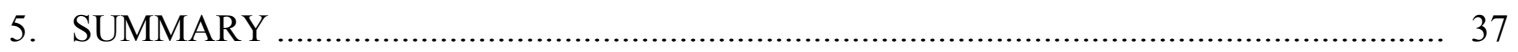

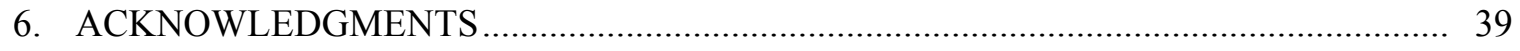

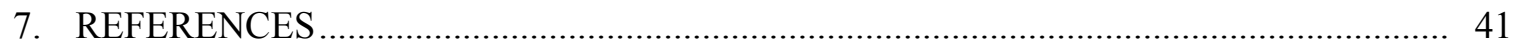





\section{LIST OF FIGURES}

Figure

Page

1 Cruise tracks and crossover points (depicted as circles) for the Atlantic

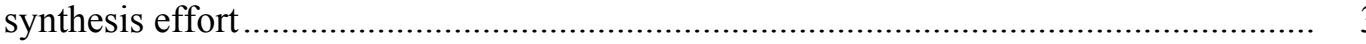

2 Number of samples vs the year that the cruise was performed.................................... 4

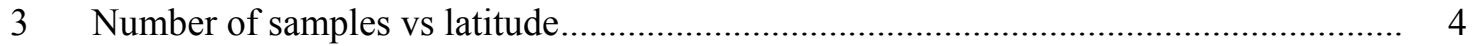

$4 \quad$ Plot of deep DIC at the Bermuda time series station (BATS) ................................... 10

5 Depth of isopycnal $45.5\left(\sigma_{4}\right)$ in the Atlantic Ocean based on cruises A16N, A16S, and A23

6 Measured - calculated (from total alkalinity and $\mathrm{pH}$ ) dissolved inorganic carbon vs latitude for A17 



\section{LIST OF TABLES}

Table

Page

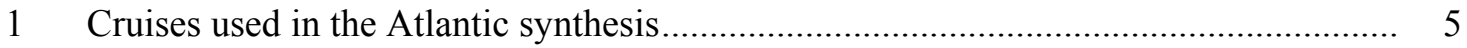

2 Analytical methods used to measure the carbon system parameters …......................... 8

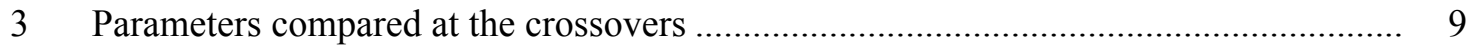

4 Summary of crossover analysis results by location ............................................... 13

5 Summary of crossover analysis results by cruise ..................................................... 19

6 Results of the multiple-parameter linear regression checks of dissolved

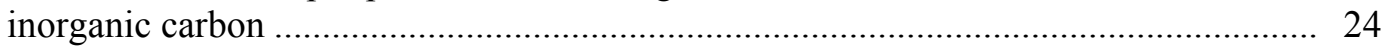

7 Results of the multiple-parameter linear regression checks of total alkalinity .............. 25

8 Summary of comparisons of overlapping cruises ................................................ 27

9 Summary of metadata for cruises with $\mathrm{pH}$ measurements....................................... 28

10 Summary of internal consistency of the Atlantic $\mathrm{CO}_{2}$ data sets ................................ 29 



\section{INVESTIGATORS}

The authors and contributors with their affiliations and addresses are as follows.

\section{Authors}

Betty Huss

NOAA, Atlantic Oceanographic and

Meteorological Laboratory (AOML)

4301 Rickenbacker Causeway

Miami, FL 33149

Kitack Lee

School of Environmental Science and

Engineering

Pohang University of Science and

Technology

San 31, Nam-gu, Hyoja-dong

Pohang, 790-784

Republic of Korea
Tsung-Hung Peng

NOAA, Atlantic Oceanographic and

Meteorological Laboratory (AOML)

4301 Rickenbacker Causeway

Miami, FL 33149

Christopher L. Sabine

NOAA, Pacific Marine Environmental

Laboratory (PMEL)

7600 Sand Point Way N.E.

Seattle, WA 98115-0070

Rik Wanninkhof

NOAA, Atlantic Oceanographic and

Meteorological Laboratory (AOML)

4301 Rickenbacker Causeway

Miami, FL 33149

\section{Contributors}

Kumiko Azetsu-Scott

Ocean Circulation Section

Ocean Sciences Division

Department of Fisheries and Oceans

Bedford Institute of Oceanography

P.O. Box 1006

Dartmouth

Nova Scotia, Canada, B2Y 4A2

John L. Bullister

NOAA, Pacific Marine Environmental

Laboratory (PMEL)

7600 Sand Point Way N.E.

Seattle, WA 98115-0070

Richard A. Feely

NOAA, Pacific Marine Environmental

Laboratory (PMEL)

7600 Sand Point Way N.E.

Seattle, WA 98115-0070
Mario Hoppema

University of Bremen, FB1

Institute of Environmental Physics

Department of Oceanography

P.O. Box 330440

Bremen

D-28334 Germany

Peter Jones

Ocean Sciences Division

Department of Fisheries and Oceans

Bedford Institute of Oceanography

P.O. Box 1006

Dartmouth

Nova Scotia, Canada, B2Y 4A2

Robert M. Key

AOS Program

Princeton University

Sayre Hall

Princeton, NJ 08544 
Alex Kozyr

U.S. Department of Energy

Carbon Dioxide Information Analysis

Center

Oak Ridge National Laboratory

Building 1509, Mail Stop 6335

Oak Ridge, TN 37831-6335

Frank J. Millero

Rosenstiel School of Marine and

Atmospheric Sciences (RSMAS)

University of Miami

4600 Rickenbacker Causeway

Miami, FL 33149
Dr. Aida F. Ríos

Instituto de Investigaciones Marinas, CSIC

c/Eduardo Cabello, 6

36208 Vigo

Spain 


\begin{abstract}
As part of the global synthesis effort sponsored by the Global Carbon Cycle project of the National Oceanic and Atmospheric Administration (NOAA) and U.S. Department of Energy, a comprehensive comparison was performed of inorganic carbon parameters measured on oceanographic surveys carried out under auspices of the Joint Global Ocean Flux Study and related programs. Many of the cruises were performed as part of the World Hydrographic Program of the World Ocean Circulation Experiment and the NOAA Ocean-Atmosphere Carbon Exchange Study. Total dissolved inorganic carbon (DIC), total alkalinity (TAlk), fugacity of $\mathrm{CO}_{2}$, and $\mathrm{pH}$ data from twenty-three cruises were checked to determine whether there were systematic offsets of these parameters between cruises. The focus was on the DIC and TAlk state variables. Data quality and offsets of DIC and TAlk were determined by using several different techniques. One approach was based on crossover analyses, where the deep-water concentrations of DIC and TAlk were compared for stations on different cruises that were within $100 \mathrm{~km}$ of each other. Regional comparisons were also made by using a multiple-parameter linear regression technique in which DIC or TAlk was regressed against hydrographic and nutrient parameters. When offsets of greater than $4 \mu \mathrm{mol} / \mathrm{kg}$ were observed for DIC and $/$ or $6 \mu \mathrm{mol} / \mathrm{kg}$ were observed for TAlk, the data taken on the cruise were closely scrutinized to determine whether the offsets were systematic. Based on these analyses, the DIC data and TAlk data of three cruises were deemed of insufficient quality to be included in the comprehensive basinwide data set. For several of the cruises, small adjustments in TAlk were recommended for consistency with other cruises in the region. After these adjustments were incorporated, the inorganic carbon data from all cruises along with hydrographic, chlorofluorocarbon, and nutrient data were combined as a researchquality product for the scientific community.
\end{abstract}





\section{ABBREVIATED TERMS}

AOML

AOU

AWI

BATS

BIO

$\mathrm{BSH}$

CDIAC

CFC

CRM

CSIC

CTD

DIC

DOE

$f \mathrm{CO}_{2}$

GCC

IEO

IPCC

IR

LDEO

LODYC

LPO

MLR

NBS

NOAA

OACES

ODV

ORSTOM

PMEL

RSMAS

SIO

SOC

SOMMA

TAlk

UEA

US JGOFS

WHOI

WHP

WOCE
Atlantic Oceanographic and Meteorological Laboratory

apparent oxygen utilization

Alfred-Wegener-Institut für Polar und Meeresforschung

Bermuda Atlantic Time-Series Station

Bedford Institute of Oceanography

Bundesamt für Seeschiffahrt und Hydrographie

Carbon Dioxide Information Analysis Center

chlorofluorocarbon

certified reference material

Consejo Superior de Investigaciones Cientificas

conductivity-temperature-depth sensor

total dissolved inorganic carbon

U.S. Department of Energy

fugacity of carbon dioxide

global carbon cycle

Instituto Español de Oceanographía

Intergovernmental Panel on Climate Change

infrared

Lamont-Doherty Earth Observatory

Laboratoire d'Océanographie Dynamique et de Climatologie

Laboratoire de Physique des Océans

multiple-parameter linear regression

National Bureau of Standards

National Oceanic and Atmospheric Administration

Ocean-Atmosphere Carbon Exchange Study

Ocean Data View

Institut Français de la Recherche Scientifique pour le Développement en Coopération

Pacific Marine Environmental Laboratory

Rosenstiel School of Marine and Atmospheric Science

Scripps Institute of Oceanography

Southampton Oceanography Centre

single-operator multiparameter metabolic analyzer

total alkalinity

University of East Anglia

U.S. Joint Global Ocean Flux Study

Woods Hole Oceanographic Institution

World Hydrographic Program

World Ocean Circulation Experiment 



\section{INTRODUCTION}

Various gases present in the Earth's atmosphere, such as water vapor $\left(\mathrm{H}_{2} \mathrm{O}\right)$, carbon dioxide $\left(\mathrm{CO}_{2}\right)$, ozone $\left(\mathrm{O}_{3}\right)$, nitrous oxide $\left(\mathrm{N}_{2} \mathrm{O}\right)$, methane $\left(\mathrm{CH}_{4}\right)$, and chlorofluorocarbons $(\mathrm{CFCs})$, absorb thermal infrared (IR) radiation, creating the phenomenon commonly called the "greenhouse effect." Human industrial and agricultural activities have led to a rapid increase in concentrations of these "greenhouse gases," raising concerns over potential climate change. Of the greenhouse gases, $\mathrm{CO}_{2}$ is the most important in terms of future global warming. Only about half of the anthropogenic $\mathrm{CO}_{2}$ emitted remains in the atmosphere; the remainder is absorbed by the ocean and terrestrial biosphere. An excellent summary of the current state of knowledge on the greenhouse gases and projected increases can be found in the reports of the Intergovernmental Panel on Climate Change (IPCC) (Houghton et al. 1995, 2001). Predicting possible global climate change caused by $\mathrm{CO}_{2}$ emissions requires forecasts of atmospheric $\mathrm{CO}_{2}$ growth. This in turn necessitates obtaining temporal and spatial data from oceans and land that can be used to model the sequestration and storage of $\mathrm{CO}_{2}$ in the oceans and terrestrial biosphere. Analysis of existing $\mathrm{CO}_{2}$ measurements is fundamental to understanding the various uptake and storage processes (sinks) for $\mathrm{CO}_{2}$ that have been observed to change on seasonal to decadal time scales. Future decisions on regulating emissions of greenhouse gases should be based on accurate models that have been adequately tested against accurate measurements.

During the 1990s, measurements of the oceanic inorganic carbon system, which are composed of total dissolved inorganic carbon (DIC), fugacity of $\mathrm{CO}_{2}\left(f \mathrm{CO}_{2}\right),{ }^{1}$ total alkalinity (TAlk), and pH, were taken on the World Hydrographic Program (WHP) cruises of the World Ocean Circulation Experiment (WOCE) and those of the Ocean-Atmosphere Carbon Exchange Study (OACES) of the National Oceanic and Atmospheric Administration (NOAA) (Fig. 1). These measurements have provided a benchmark of unsurpassed accuracy for the ocean inventory of $\mathrm{CO}_{2}$ and other properties. The inorganic carbon measurements performed by U.S. investigators were cosponsored by NOAA and the U.S. Department of Energy (DOE) as part of the U.S. Joint Global Ocean Flux Study (US JGOFS) Program. In addition to the U.S. cruises, the Atlantic synthesis included a significant number of cruises sponsored by the science agencies of the foreign nations. This report addresses the consistency of oceanic inorganic carbon system parameter measurements taken from 1990 to 1998 in the northern and southern Atlantic Ocean and lists adjustments to some of the DIC and TAlk measurements based on careful analysis of the full data set.

The analysis of the large-scale data quality of inorganic carbon system parameters for the Atlantic syntheses data set followed the procedures outlined in Lamb et al. (2001) and Feely et al. (1999) with the objective of determining the consistency of inorganic carbon data among the different cruise data. The focus was on the DIC and TAlk state variables used in the calculation of the anthropogenic $\mathrm{CO}_{2}$ inventory and for studies of biogeochemical carbon cycling. Four approaches were followed to determine whether there were systematic offsets in the cruise data sets.

A. Inorganic carbon system values in deep water were compared where cruise tracks cross, hereafter referred to as "crossover analyses."

B. Multiple-parameter linear regressions (MLRs) of DIC or TAlk with potential temperature, salinity, oxygen, silicate, and nitrate were created from data of cruises that followed a similar

\footnotetext{
${ }^{1}$ The fugacity of $\mathrm{CO}_{2}$ is the partial pressure of carbon dioxide $\left(\mathrm{pCO}_{2}\right)$ corrected for non-ideality of the gas (Weiss 1974). $f \mathrm{CO}_{2} \approx 0.996 \mathrm{pCO}_{2}$; the terms are often used interchangeably.
} 
cruise track. The calculated values were then compared with the measured parameters for each of the cruises.

C. On cruises where more than two carbon system parameters were measured, the internal consistency between parameters was evaluated by using known thermodynamic relationships between the parameters.

D. Finally, regional MLR regressions of DIC or TAlk with potential temperature, salinity, oxygen, silicate, and nitrate were created from all data in a particular region; data deemed good based on the previous checks were used. These fits were used together with hydrographic data from individual cruises to investigate differences between the calculated DIC or TAlk and the measured values.

The cruise lines used are shown in Fig. 1, and the distribution of data vs time and latitude are presented in Figs. 2 and 3, respectively. Observations decreased in 1995 and 1996 because the WOCE/WHP and OACES programs were focusing on the Indian Ocean during those years. The observations vs latitude show a reasonably uniform coverage for the carbon system parameters. Of note is the absence of alkalinity data in the Atlantic sector of the Southern Ocean.

In the crossover analyses, the four inorganic carbon system parameters (DIC, $f \mathrm{CO}_{2}, \mathrm{TAlk}$, and $\mathrm{pH})$ were compared in density space referenced to $4000 \mathrm{~dB}\left(\sigma_{4}\right)$ at 53 locations where cruises overlapped throughout the Atlantic Ocean (Fig. 1, Table 1). Such comparisons have been made for oceanic carbon parameters in the Indian Ocean (Johnson et al. 1998, Millero et al. 1998, Sabine et al. 1999) and the Pacific Ocean (Lamb et al. 2001). Similar comparisons are under way for nutrient data (Gordon et al. 1998) and CFC data (Smethie, personal communication).

The analyses presented in this report are the basis for recommending adjustments to the data sets to form a consistent basin-wide unified data set. The corrected working data set, which includes the original carbon data as well, is provided as two large datafiles at the following web site: http://www.aoml.noaa.gov/ocd/oaces/atlantic_synthesis.html. The Atlantic data set in combination with those from the Indian and Pacific oceans will provide the first comprehensive global data set of DIC and TAlk to the research community. The Carbon Dioxide Information Analysis Center (CDIAC) web site (http://cdiac.esd.ornl.gov/oceans/home.html) will house all three corrected data sets. Data from the individual cruises can be found on the CDIAC site as well. 
Crossover Locations in the North and South Atlantic

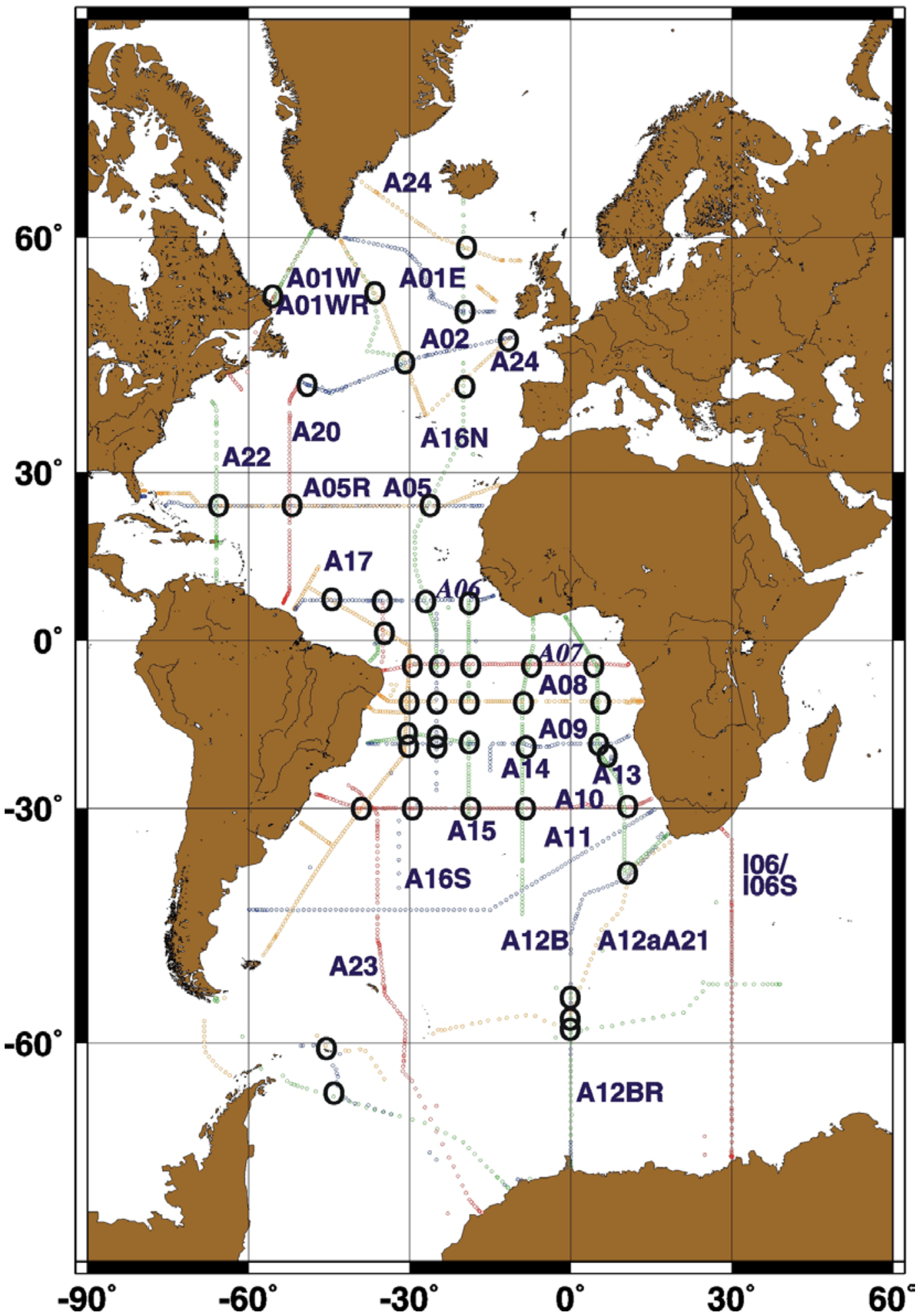

Fig. 1. Cruise tracks and crossover points (depicted as circles) for the Atlantic synthesis effort. 


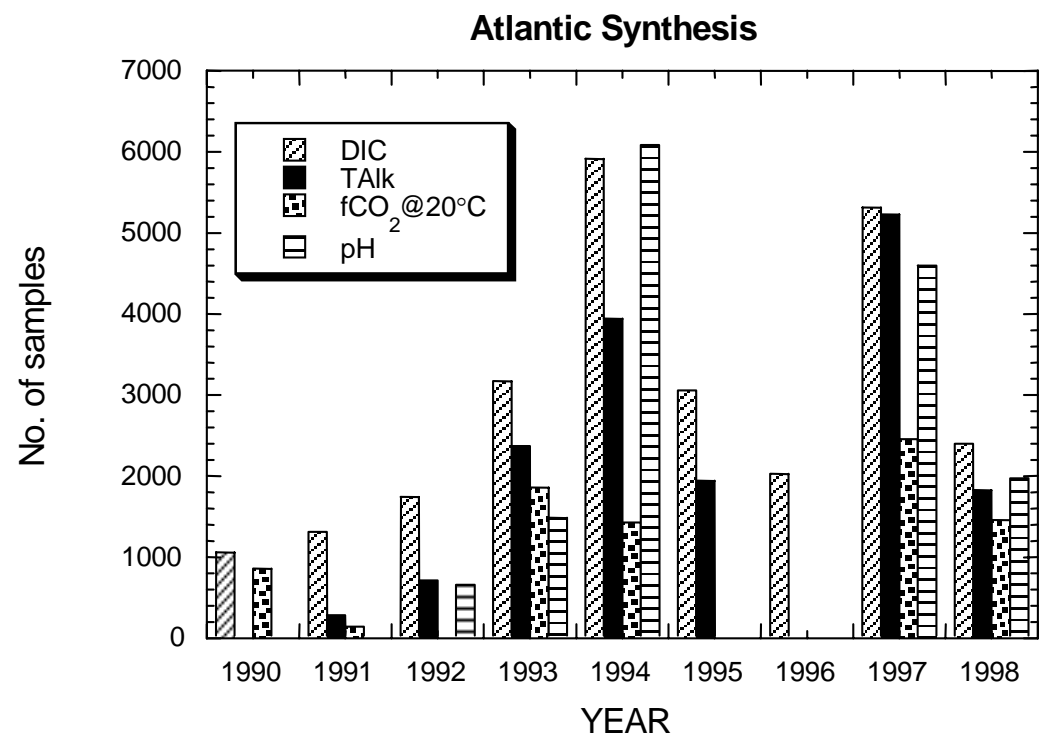

Fig. 2. Number of samples vs the year that the cruise was performed. (Note: the tally excludes A06 and A07.)

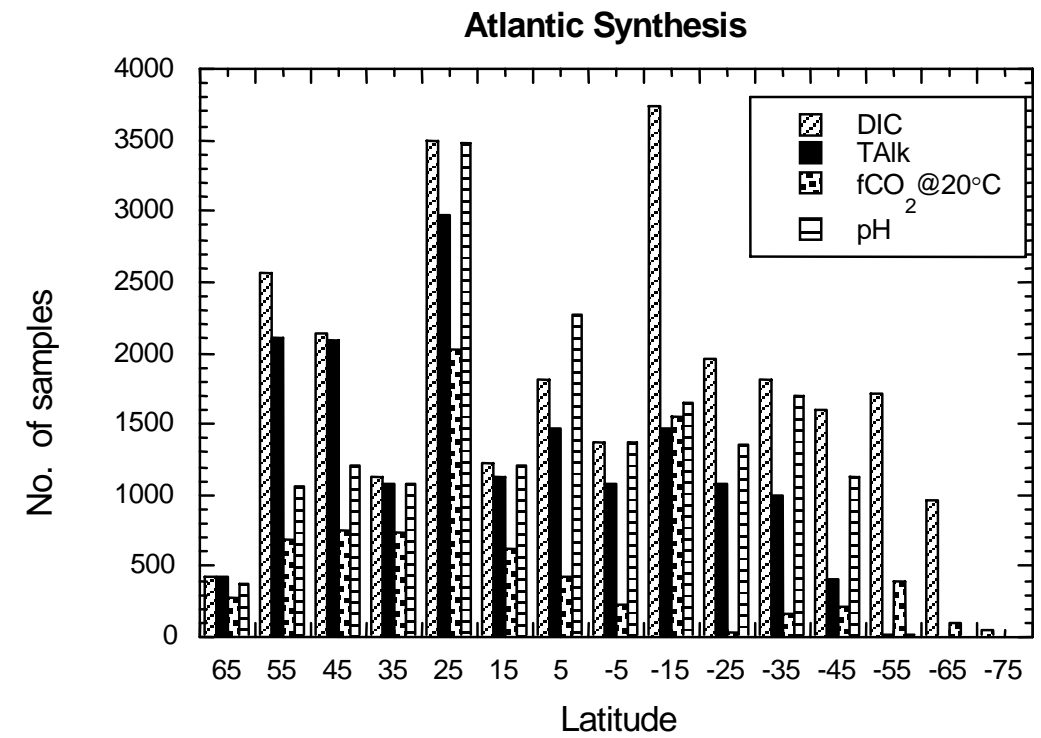

Fig. 3. Number of samples vs latitude. (Note: the tally excludes A06 and A07.) 
Table 1. Cruises used in the Atlantic synthesis

\begin{tabular}{|c|c|c|c|c|c|c|}
\hline No. & $\begin{array}{l}\text { Cruise name } \\
\text { EXPO code }^{a}\end{array}$ & Research vessel & Period & Chief scientist $^{b}$ & Carbon-related data contributor ${ }^{b}$ & Variables in data set ${ }^{b}$ \\
\hline 1 & $\begin{array}{l}\text { A21/A12 } \\
\text { 06MT11_5 }\end{array}$ & $\mathrm{R} / \mathrm{V}$ Meteor $11 / 5$ & $1 / 23 / 90-3 / 8 / 90$ & W. Roether/Univ. of Bremen & T. Takahashi/LDEO & Hydrogr., Nutr., DIC, $f \mathrm{CO}_{2}, \mathrm{CFC}$ \\
\hline 2 & $\begin{array}{l}\text { A09 } \\
06 \mathrm{MT} 15 \_3\end{array}$ & R/V Meteor 15 & $2 / 10 / 91-3 / 23 / 91$ & G. Siedler/Univ. of Kiel & D. Wallace/Univ. of Kiel & $\begin{array}{l}\text { Hydrogr., Nutr., DIC, TAlk, } f \mathrm{CO}_{2} \text {, } \\
\text { CFC }\end{array}$ \\
\hline 3 & $\begin{array}{l}\text { A16S } \\
\text { OACES91_1/2 }\end{array}$ & $\mathrm{R} / \mathrm{V}$ Baldridge & $7 / 11 / 91-9 / 2 / 91$ & D. K. Atwood/AOML & R. Wanninkhof/AOML & $\begin{array}{l}\text { Hydrogr., Nutr., DIC, } f \mathrm{CO}_{2} \text {, TAlk, } \\
\text { underw. } f \mathrm{CO}_{2}\end{array}$ \\
\hline 4 & $\begin{array}{l}\text { A01E } \\
06 \mathrm{MT} 18 \_1\end{array}$ & R/V Meteor $18 / 1$ & $9 / 2 / 91-9 / 26 / 91$ & D. Meincke/Univ. of Hamburg & D. Wallace/Univ. of Kiel & $\begin{array}{l}\text { Hydrogr., Nutr., DIC, TAlk, underw. } \\
f \mathrm{CO}_{2}\end{array}$ \\
\hline 5 & $\begin{array}{l}\text { A12B } \\
\text { 06AQANTX_4 }\end{array}$ & Polarstern & $5 / 21 / 92-8 / 5 / 92$ & P. Lemke/Univ. of Kiel & M. Hoppema/Univ. of Bremen & Hydrogr., Nutr., DIC \\
\hline 6 & $\begin{array}{l}\text { A05 } \\
\text { 29HE06_1 }\end{array}$ & $\mathrm{R} / \mathrm{V}$ Hesperides & $7 / 15 / 92-8 / 16 / 92$ & G. Parrilla/IEO, Spain & A. Ríos/CSIC, Spain & Hydrogr, Nutr., DIC, TAlk, pH \\
\hline 7 & $\begin{array}{l}\text { A10 } \\
06 \mathrm{MT} 22 \_5\end{array}$ & R/V Meteor 22 & $12 / 27 / 92-1 / 31 / 93$ & R. Onken/Univ. of Kiel & D. Wallace/Univ. of Kiel & $\begin{array}{l}\text { Hydrogr., Nutr., DIC, TAlk, CFC, } \\
\text { underw. } f \mathrm{CO}_{2}\end{array}$ \\
\hline 8 & $\begin{array}{l}\text { A11 } \\
\text { 74DI199_1 }\end{array}$ & R/V Discovery & $12 / 22 / 92-2 / 1 / 93$ & P. Saunders/SOC & רิน & Hydrogr., Nutr., CFC \\
\hline 9 & $\begin{array}{l}\text { A07 } \\
\text { 35A3CITHER1_2 }\end{array}$ & $\mathrm{R} / \mathrm{V}$ L'Atalante & $1 / 2 / 93-2 / 10 / 93$ & A. Moliere/LODYC & C. Oudot/ORSTOM, Brest, France & $\begin{array}{l}\text { Hydrogr., Nutr., DIC, TAlk, } f \mathrm{CO}_{2} \text {, } \\
\text { pH, CFC }\end{array}$ \\
\hline 10 & $\begin{array}{l}\text { A06 } \\
\text { 35A3CITHER1_2 }\end{array}$ & $\mathrm{R} / \mathrm{V}$ L'Atalante & $2 / 13 / 93-3 / 19 / 93$ & A. Moliere/C. Colin & C. Oudot/ORSTOM, Brest, France & $\begin{array}{l}\text { Hydrogr., Nutr., DIC, TAlk, } f \mathrm{CO}_{2} \text {, } \\
\text { pH, CFC }\end{array}$ \\
\hline 11 & $\begin{array}{l}\text { A16N } \\
\text { OACES93 }\end{array}$ & $\mathrm{R} / \mathrm{V}$ Baldrige & $7 / 4 / 93-8 / 30 / 93$ & R. Wanninkhof/AOML & R. Wanninkhof/AOML & $\begin{array}{l}\text { Hydrogr., Nutr., DIC, TAlk, } f \mathrm{CO}_{2} \text {, } \\
\text { pH, CFC, underw. } f \mathrm{CO}_{2}\end{array}$ \\
\hline 12 & $\begin{array}{l}\text { A17 } \\
3230 \text { CITHER2_1/2 }\end{array}$ & $\mathrm{R} / \mathrm{V}$ M Ewing & $1 / 4 / 94-3 / 22 / 94$ & L. Memery/LODYC & D. Wallace/A. Ríos & $\begin{array}{l}\text { Hydrogr., Nutr., DIC, TAlk, pH, } \\
\text { CFC, underw. } f \mathrm{CO}_{2}\end{array}$ \\
\hline 13 & $\begin{array}{l}\text { A15 } \\
316 \mathrm{~N} 142 \_3\end{array}$ & R/V Knorr & $4 / 3 / 94-5 / 21 / 94$ & W Smethie/LDEO & C. Goyet/WHOI & Hydrogr., Nutr., DIC, TAlk \\
\hline 14 & $\begin{array}{l}\text { A08 } \\
\text { 06MT28_1 }\end{array}$ & $\mathrm{R} / \mathrm{V}$ Meteor & $3 / 29 / 94-5 / 11 / 94$ & T. Mueller/Univ. of Kiel & D. Wallace/Univ. of Kiel & Hydrogr., Nutr., DIC, $f \mathrm{CO}_{2}$ \\
\hline 15 & $\begin{array}{l}\text { A14 } \\
\text { 35A3CITHER3_1 }\end{array}$ & $\mathrm{R} / \mathrm{V}$ L'Atalante & $1 / 17 / 95-2 / 11 / 95$ & M. Arhan/LPO & D. Wallace/A. Ríos & $\begin{array}{l}\text { Hydrogr., Nutr., DIC, TAlk, } \mathrm{pH} \text {, } \\
\text { CFC, underw. } f \mathrm{CO}_{2}\end{array}$ \\
\hline 16 & $\begin{array}{l}\text { A13 } \\
\text { 35A3CITHER3_2 }\end{array}$ & $\mathrm{R} / \mathrm{V}$ L'Atalante & $2 / 22 / 95-3 / 28 / 95$ & M. Arhan/LPO & $\begin{array}{l}\text { D. Wallace/Univ. of Kiel } \\
\text { A. Ríos/CSIC, Spain }\end{array}$ & Hydrogr., Nutr., DIC, TAlk, CFC \\
\hline 17 & $\begin{array}{l}\text { A23 } \\
\text { 74JC10_1 }\end{array}$ & RSS JC Ross & $3 / 20 / 95-5 / 6 / 95$ & $\begin{array}{l}\text { B. King/SOC } \\
\text { K. Heywood/UEA }\end{array}$ & Robertson/SOC, England & Hydrogr., Nutr., DIC, $f \mathrm{CO}_{2}, \mathrm{CFC}$ \\
\hline 18 & $\begin{array}{l}\text { A01W } \\
\text { 18HU95011_1 }\end{array}$ & R/V Hudson & $6 / 7 / 95-7 / 5 / 95$ & J. Lazier/BIO, Canada & P. Jones/BIO, Canada & Hydrogr., Nutr., DIC, TAlk, CFC \\
\hline 19 & $\begin{array}{l}\text { IO6 } \\
\text { 35MF103 } 1\end{array}$ & R/V M. Dufresne & $2 / 20 / 96-3 / 22 / 96$ & A. Poisson/Univ. of Paris & A. Poisson/Univ. of Paris & Hydrogr., Nutr., DIC, TAlk, CFC \\
\hline
\end{tabular}


Table 1 (continued)

\begin{tabular}{|c|c|c|c|c|c|c|}
\hline No. & $\begin{array}{l}\text { Cruise name } \\
\text { EXPO code }^{a}\end{array}$ & $\begin{array}{l}\text { Research } \\
\text { vessel }\end{array}$ & Period & Chief scientist ${ }^{b}$ & Carbon-related data contributor ${ }^{b}$ & Variables in data set ${ }^{b}$ \\
\hline 20 & $\begin{array}{l}\text { A12BR (SR04) } \\
\text { 06AQANTXIII_4 }\end{array}$ & Polarstern & $3 / 17 / 96-5 / 20 / 96$ & E. Fahrbach/AWI & M. Hoppema/Univ. of Bremen & Hydrogr., Nutr., DIC, CFC \\
\hline 21 & $\begin{array}{l}\text { A02 } \\
\text { 06MT39_3 }\end{array}$ & $\mathrm{R} / \mathrm{V}$ Meteor & $6 / 11 / 97-7 / 3 / 97$ & P. Koltermann/BSH & D. Wallace/Univ. of Kiel & Hydrogr., DIC, TAlk \\
\hline 22 & $\begin{array}{l}\mathrm{A} 20 \\
316 \mathrm{~N} 151 \_3\end{array}$ & R/V Knorr & $7 / 17 / 97-8 / 10 / 97$ & R. Pickart/WHOI & $\begin{array}{l}\text { F. Millero/RSMAS } \\
\text { C. Sabine/PMEL; D. Wallace }\end{array}$ & $\begin{array}{l}\text { Hydrogr., Nutr., DIC, TAlk, } f \mathrm{CO}_{2} \text {, } \\
\text { pH, CFC }\end{array}$ \\
\hline 23 & $\begin{array}{l}\text { A22 } \\
316 \mathrm{~N} 151 \_4\end{array}$ & R/V Knorr & $8 / 15 / 97-9 / 3 / 97$ & T. Joyce/WHOI & $\begin{array}{l}\text { F. Millero/RSMAS } \\
\text { C. Sabine, D. Wallace }\end{array}$ & $\begin{array}{l}\text { Hydrogr., Nutr., DIC, TAlk, } f \mathrm{CO}_{2} \text {, } \\
\text { pH, CFC }\end{array}$ \\
\hline 24 & $\begin{array}{l}\text { A24 } \\
316 \mathrm{~N} 151 \_2\end{array}$ & R/V Knorr & $8 / 15 / 97-9 / 3 / 97$ & L. Talley/SIO & $\begin{array}{l}\text { F. Millero/RSMAS } \\
\text { D. Wallace/Univ. of Kiel }\end{array}$ & $\begin{array}{l}\text { Hydrogr., Nutr., DIC, TAlk, } f \mathrm{CO}_{2} \text {, } \\
\text { pH }\end{array}$ \\
\hline 25 & $\begin{array}{l}\text { A05R } \\
\text { OACES98 }\end{array}$ & $\mathrm{R} / \mathrm{V}$ Brown & $1 / 24 / 98-2 / 23 / 98$ & K. Lee/AOML & R. Wanninkhof/AOML & $\begin{array}{l}\text { Hydrogr., Nutr., DIC, TAlk, pH, } \\
f \mathrm{CO}_{2}, \mathrm{CFC}\end{array}$ \\
\hline 26 & $\begin{array}{l}\text { A01WR (AR07W) } \\
\text { 18HU98023 1 }\end{array}$ & CCGS Hudson & $6 / 22 / 98-7 / 8 / 98$ & P. Jones/BIO, Canada & P. Jones/BIO, Canada & Hydrogr., Nutr., DIC, TAlk, CFC \\
\hline
\end{tabular}

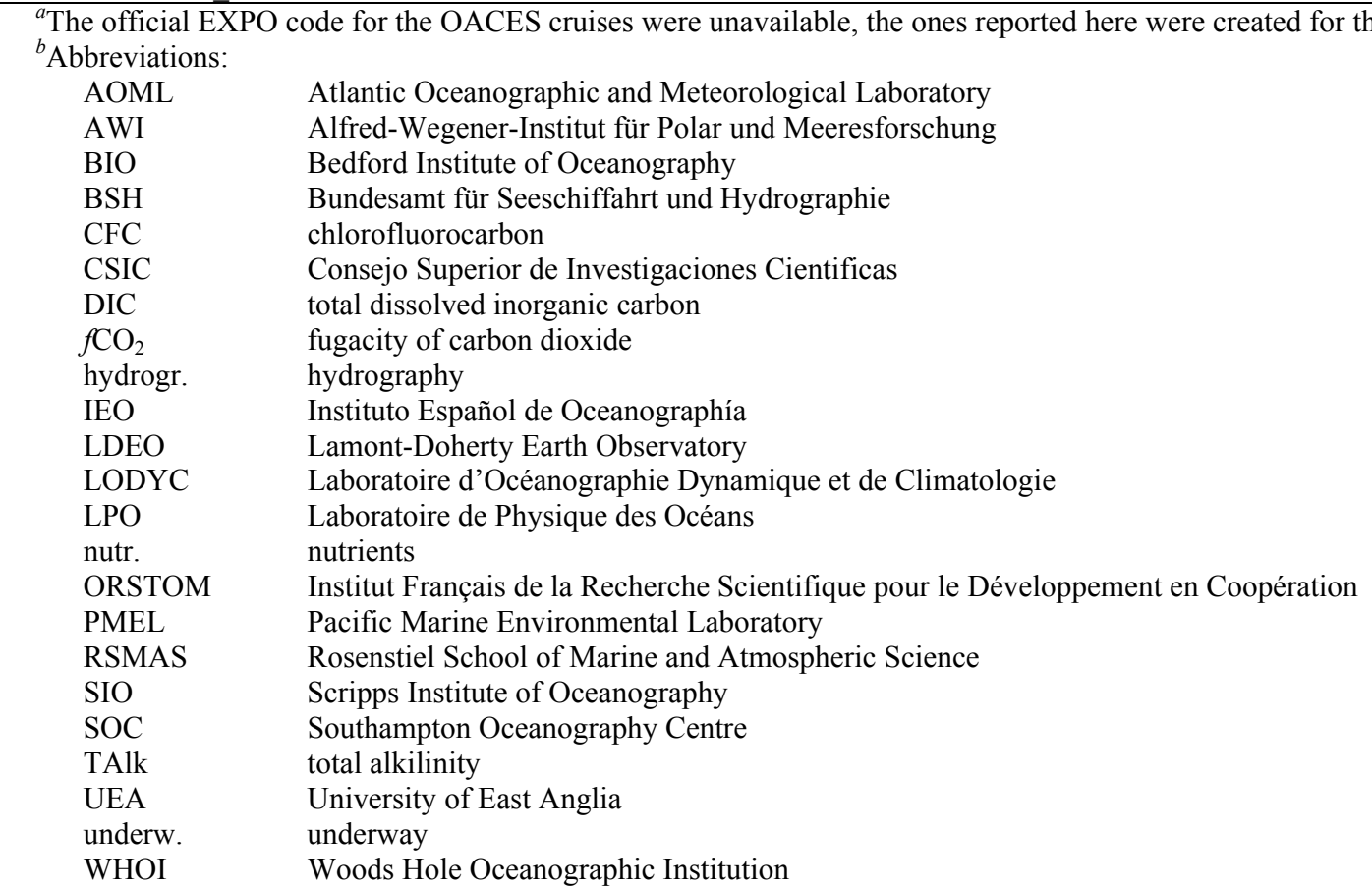




\section{ANALYTICAL METHODS}

Several significant advances in the chemical analysis of inorganic carbon system parameters occurred immediately prior to and during the inorganic carbon survey on the WOCE/WHP and OACES cruises. Many of the DIC measurements were performed by using a coulometer, often connected to a single-operator multiparameter metabolic analyzer (SOMMA), which has greater precision than previous techniques. For the U.S. cruises and many of the (later) foreign cruises, standard operating protocols were applied following the techniques outlined in the Handbook of Methods for the Analysis of the Various Parameters of the Carbon Dioxide System in Sea Water (DOE 1994). Certified reference materials (CRMs) were used on all U.S. cruises and on many non-U.S. cruises as secondary standards for DIC analyses. Discussion of the preparation and use of CRMs for DIC and TAlk is presented in detail in Dickson, Afgan, and Anderson (accepted) and Dickson, Anderson, and Afgan (submitted) (see also http://www-mpl.ucsd.edu/people/ adickson/CO2_QC/). The CRMs consisted of natural seawater that was filtered, sterilized, and poisoned. Certification of the CRMs for DIC is based on manometric analyses in the shore-based laboratory of C. D. Keeling of Scripps Institution of Oceanography (SIO) over a period of several years. The CRMs were bottled in large batches into $500-\mathrm{mL}$ borosilicate glass containers, sealed to prevent contamination, and shipped to the users. They were then analyzed at sea interspersed with samples over the course of each of the cruises as a way of verifying accuracy. Because CRMs were routinely analyzed for DIC during most cruises, groups analyzing TAlk on those cruises often measured CRMs for their alkalinity content. This enabled post-cruise corrections to be made to TAlk data based on archived CRMs that were analyzed at C. D. Keeling's laboratory and at the laboratory of F. Millero in Miami.

Insufficient metadata precluded a determination of which cruises had adjustments applied for TAlk based on CRM analyses. CRMs were not available for the other two carbon parameters discussed in this report $\left(f \mathrm{CO}_{2}\right.$ and $\left.\mathrm{pH}\right)$. However, for some of the cruises the CRMs were used to normalize the $\mathrm{pH}$ values by calculating the $\mathrm{pH}$ of the CRMs from the certified TAlk and DIC values. Analyses of salinity, nutrients, and $\mathrm{O}_{2}$ followed WOCE WHP protocol (WOCE 1994).

Analytical procedures differed between cruises. SOMMAs were used for all of the cruises that had U.S. investigators performing the DIC measurements (Johnson et al. 1993). For non-U.S. investigators, other procedures were used, ranging from use of coulometers with manual or automated pipettes to analysis by gas chromatography (Table 2). For some cruises, DIC was determined from TAlk and $\mathrm{pH}$. The TAlk was measured by potentiometric titration logging of either a full titration curve (referred to as "Full" in Table 2) (Millero et al. 1993) or single-point titrations ("1-point") (Perez and Fraga 1987). For cruises A6 and A7, we were unable to find the appropriate metadata describing how the alkalinities were measured. The $\mathrm{pH}$ measurements were done by electrode, spectrophotometric, or potentiometric determination (Byrne and Breland 1989). Discrete $f \mathrm{CO}_{2}$ was measured by equilibration of a discrete sample with a headspace with known initial concentration and by subsequent IR analysis (Wanninkhof and Thoning 1993) or gas chromatography (Chipman, Marra, and Takahashi 1993, Neil et al. 1997). 
Table 2. Analytical methods used to measure the carbon system parameters

\begin{tabular}{|c|c|c|c|c|c|c|}
\hline No. & $\begin{array}{l}\text { Cruise } \\
\text { name }\end{array}$ & Period & $\begin{array}{l}\text { Dissolved inorganic } \\
\text { carbon }\end{array}$ & $\begin{array}{l}\text { Total } \\
\text { alkalinity }\end{array}$ & $\mathrm{CO}_{2}$ fugacity & pH \\
\hline 1 & A21/A12 & $1 / 23 / 90-3 / 8 / 90$ & Coulometer & - & Gas chromatography $^{b}$ & - \\
\hline 2 & A09 & $2 / 10 / 91-3 / 23 / 91$ & SOMMA $^{c}$ & Full $^{d}$ & - & - \\
\hline 3 & A16S & 7/11/91-9/2/91 & SOMMA & Full & Infrared analysis $^{e}$ & - \\
\hline 4 & A01E & $9 / 2 / 91-9 / 26 / 91$ & SOMMA & Full & - & - \\
\hline 5 & A12B & $5 / 21 / 92-8 / 5 / 92$ & Coulometer & - & - & - \\
\hline 6 & A05 & $7 / 15 / 92-7 / 23 / 92$ & Calculated & 1-point & - & Electrode \\
\hline 7 & A10 & $12 / 27 / 92-1 / 31 / 93$ & SOMMA & Full & - & - \\
\hline 8 & A11 & $12 / 22 / 92-2 / 1 / 93$ & - & - & - & - \\
\hline 9 & $\mathrm{~A} 07$ & $1 / 2 / 93-1 / 10 / 93$ & Gas chromatography & - & Gas chromatography & Electrode \\
\hline 10 & A06 & $1 / 2 / 93-3 / 19 / 93$ & Gas chromatography & - & Gas chromatography & Electrode \\
\hline 11 & $\mathrm{~A} 16 \mathrm{~N}$ & $7 / 4 / 93-8 / 30 / 93$ & SOMMA & Full & Infrared analysis ${ }^{e}$ & Spectrophotometric \\
\hline 12 & A17 & $1 / 4 / 94-3 / 22 / 94$ & SOMMA & 1-point & - & Potentiometric ${ }^{f}$ \\
\hline 13 & A15 & $4 / 3 / 94-5 / 21 / 94$ & SOMMA & Full & - & - \\
\hline 14 & A08 & $3 / 29 / 94-5 / 11 / 94$ & SOMMA & - & Gas chromatography ${ }^{g}$ & - \\
\hline 15 & A13 & $2 / 20 / 95-3 / 2 / 95$ & SOMMA & 1-point & - & - \\
\hline 16 & A 14 & $1 / 12 / 95-2 / 16 / 95$ & SOMMA & 1-point & - & Potentiometric \\
\hline 17 & A23 & $3 / 20 / 95-5 / 6 / 95$ & Coulometer & - & Gas chromatography $^{h}$ & - \\
\hline 18 & $\mathrm{~A} 01 \mathrm{~W}$ & $6 / 95-7 / 95$ & Coulometer & Full & - & - \\
\hline 19 & A12BR & $3 / 17 / 96-5 / 20 / 96$ & Coulometer & - & - & - \\
\hline 20 & A02 & $6 / 11 / 97-7 / 3 / 97$ & SOMMA & Full & - & - \\
\hline 21 & A 20 & $7 / 17 / 97-8 / 10 / 97$ & SOMMA & Full & - & Electrode \\
\hline 22 & A22 & 8/15/97-9/3/97 & SOMMA & Full & - & Electrode \\
\hline 23 & A24 & 8/15/97-9/3/97 & SOMMA & Full & - & Electrode \\
\hline 24 & A05R & $1 / 24 / 98-2 / 23 / 98$ & SOMMA & Full & Gas chromatography ${ }^{g}$ & Spectrophotometric \\
\hline 25 & A01WR & $6 / 22 / 98-7 / 8 / 98$ & Coulometer & Full & - & Electrode \\
\hline \multicolumn{7}{|c|}{${ }^{a}$ Determined by potentiometric titration, either a full curve (“Full”) or a single-point (“1-point”) titration. } \\
\hline \multicolumn{7}{|c|}{${ }^{b} 500-\mathrm{mL}$ samples, analysis by gas chromatography. (Chipman, D. W., J. Marra, and T. Takahashi. Primary production at } \\
\hline \multicolumn{7}{|c|}{$\begin{array}{l}47^{\circ} \mathrm{N} \text { and } 20^{\circ} \mathrm{W} \text { in the North Atlantic Ocean: A comparison between the }{ }^{14} \mathrm{C} \text { incubation method and mixed layer carbon } \\
\text { budget observations. Deep-Sea Research II 40, 151-69, 1993.) }\end{array}$} \\
\hline \multicolumn{7}{|c|}{${ }^{c}$ Single-operator multiparameter metabolic analyzer. } \\
\hline \multicolumn{7}{|c|}{${ }^{d}$ Analyzed shoreside. } \\
\hline \multirow{3}{*}{\multicolumn{7}{|c|}{$\begin{array}{l}e^{e} 500 \text {-mL samples, infrared analysis. [Wanninkhof, R., and K. Thoning. Measurement of fugacity of } \mathrm{CO}_{2} \text { in surface water } \\
\text { using continuous and discrete sampling methods. Mar. Chem. } 44(2-4), 189-205,1993 .] \\
{ }_{f}^{A} 17 \mathrm{C} \text { only. }\end{array}$}} \\
\hline & & & & & & \\
\hline \multicolumn{5}{|c|}{${ }^{g} 60-$ or $120-\mathrm{mL}$ samples, analysis by gas chromatography. (Neill, C., K. M. Joh } & & \\
\hline \multicolumn{7}{|c|}{$\begin{array}{l}\text { Small volume, batch equilibration measurement of } f \mathrm{CO}_{2} \text { in discrete water samples. Limnol. Oceanogr. 42, 1774-83, 1997.) } \\
{ }_{h} \text { Measured at } 4^{\circ} \mathrm{C} \text {. }\end{array}$} \\
\hline
\end{tabular}




\section{PROCEDURES TO DETERMINE OFFSETS}

The quality of all data used in the analyses was extensively controlled by the investigators responsible for the measurements. Therefore, significant care was taken to avoid suggesting erroneous corrections. This is why different and largely independent approaches were used to look for biases. Adjustments were recommended only if there were clear-cut and consistent differences of greater than $4 \mu \mathrm{mol} / \mathrm{kg}$ for DIC and $6 \mu \mathrm{mol} / \mathrm{kg}$ for TAlk. The cutoffs correspond to about twice the precision of the measurements performed on the cruises based on replicate and deep-water comparisons. Issues of data variability with depth and/or station-to-station variability were more frequent than clear-cut offsets. Sometimes the variability was large enough to question the integrity and utility of the cruise for the purposes of large-scale integration.

Several methods were used to assess the consistency among DIC and TAlk data from the cruises. For the first method, cruise-to-cruise comparisons of measurements were performed at crossover points for deep water $(>1500 \mathrm{~m})$. The assumption was that variability in deep water would be very small and that the anthropogenic signal, which would complicate the comparison of cruise data spanning eight years, would be negligible. The analysis was performed in density space to avoid biases due to movement of water masses. The method incorporated the implicit assumption that there were no systematic biases with density over the time period. Several recent investigations have shown changes in properties throughout the water column, but limited timeseries work suggests that the changes are smaller than the level of agreement we are striving for ( $4 \mu \mathrm{mol} / \mathrm{kg}$ for DIC and $6 \mu \mathrm{mol} / \mathrm{kg}$ for TAlk). For instance, the time series station data at Bermuda show constancy in deep-water DIC values to within $3 \mu \mathrm{mol} / \mathrm{kg}$ (Fig. 4) (Nick Bates, personal communication).

In total, 53 crossovers were investigated. The breakdown of carbon parameters compared at the crossovers is shown in Table 3 . As the table indicates, 20 of the 53 total crossovers had DIC as a common parameter for the junction of cruises; 16 had comparable TAlk and DIC data on both cruises. For 17 of the crossovers, three or four carbon system parameters were measured on both cruises.

Table 3. Parameters compared at the crossovers

\begin{tabular}{lc}
\hline Parameter & No. of crossovers \\
\hline DIC only & 19 \\
DIC and TAlk only & 17 \\
DIC and $f \mathrm{CO}_{2}$ only & 0 \\
DIC and pH only & 0 \\
Three or four parameters & 17 \\
$\quad$ Total & 53 \\
\hline
\end{tabular}

The second method was used for cruises that covered a similar cruise track. It involved an MLR of DIC or TAlk with parameters known to influence DIC or TAlk levels and/or those that are known to regress with DIC or TAlk. The measurements for the overlapping cruises were combined for depths generally greater than $1500 \mathrm{~m}$, and the regression coefficients were determined for DIC or TAlk with $\mathrm{T}, \mathrm{S}, \mathrm{SiO}_{2}$, apparent oxygen utilization (AOU), and $\mathrm{NO}_{3}$. The calculated DIC or TAlk values from this MLR were then compared with the measured values to determine systematic differences among cruises. This method of comparison was applied to ten cruises that overlapped in space.

The third method involved assessment of internal consistency for cruises in which three or more inorganic carbon system parameters were measured. In this approach, the thermodynamic relationships of Mehrbach et al. (1973) as refit by Dickson and Millero (1987) were used to calculate DIC from TAlk and $f \mathrm{CO}_{2}$ or $\mathrm{pH}$ (or to calculate TAlk from DIC and $f \mathrm{CO}_{2}$ or $\mathrm{pH}$ ). The calculated values were then compared with the measured values. When significant differences are found between calculated and measured values, this approach does not a priori establish which of 


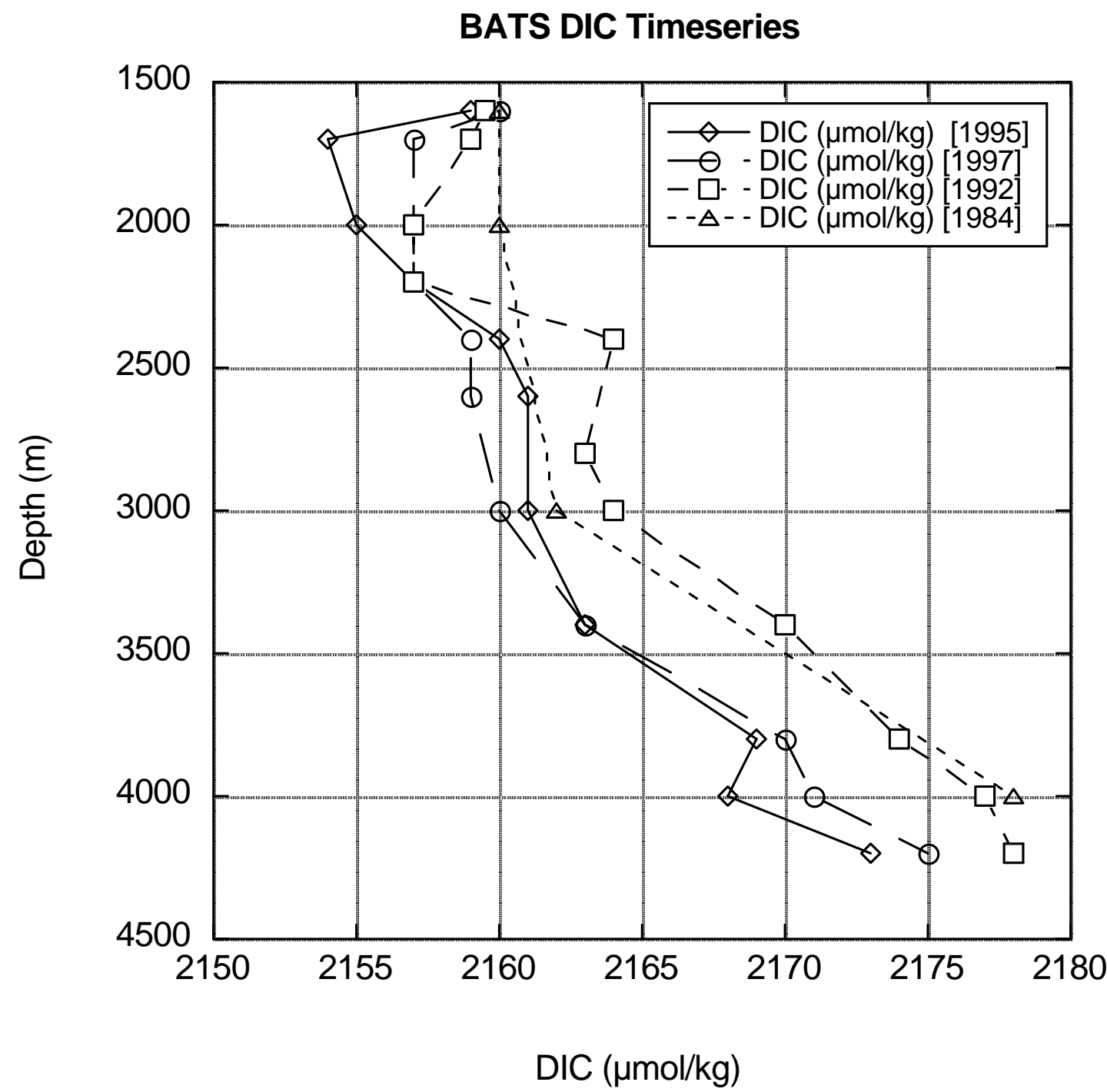

Fig. 4. Plot of deep DIC at the Bermuda time series station (BATS). The circles are data for 1997, the diamonds for 1995, and the open squares for 1992. The open triangles are samples from nearby Hydrostation S for 1984, analyzed by manometry by C. D. Keeling of the Scripps Institute of Oceanography. The small changes are a combination of inaccuracy in measurements and watermass movement (data courtesy of Nick Bates, Bermuda Biological Station for Research).

the three parameters is in error, but the results can be used with the other methods to identify the culprit. Ten cruises had three or four inorganic carbon system parameters for which this approach could be applied.

The fourth method used the same MLR technique as was used in the overlapping cruise comparisons, but it was applied to cruises in a particular region. The regression fit was determined by using the cruises that had met the crossover criteria in a particular region for depths greater than $1500 \mathrm{~m}$. The relevant data from all cruises were separated into three regions with distinctly different fits for the regressions: (1) The subtropical and polar regions north of $15^{\circ} \mathrm{N},(2)$ the equatorial region between $15^{\circ} \mathrm{N}$ and $15^{\circ} \mathrm{S}$, and (3) the subtropical and polar region 
south of $15^{\circ} \mathrm{S}$. The DIC and TAlk data for the individual cruises within each region were then compared with the calculated values from the corresponding regressions.

\subsection{Crossover Analyses}

Before the detailed crossover analyses were performed, all relevant parameters at crossover locations were inspected for overall data integrity. Data were imported into Ocean Data View (ODV), a data-visualization program available as freeware at http://www.awi-bremerhaven.de $/ \mathrm{GEO} / \mathrm{ODV} /$. For each crossover, all stations within a $1^{\circ}(\approx 100 \mathrm{~km})$ radius of each other were included for analysis. Individual ODV profiles were created of the carbon parameters, temperature, salinity, oxygen, nitrate, phosphate, and silicate vs full water depth. Each crossover plot was visually inspected for offsets among the cruises that might be consistent across the hydrographic, nutrient, and carbon parameters. Such consistent offsets might indicate that different water masses were sampled on the two cruises. This first look also allowed us to detect errors such as improper recording of the measurement temperature for $f \mathrm{CO}_{2}$ or an incorrectly labeled reference scale or measurement temperature for $\mathrm{pH}$. After this visual inspection was completed, more rigorous approaches were performed to quantify offsets in carbon system parameters.

The crossover analyses involved the comparison of one to four inorganic carbon-system parameters (DIC, $f \mathrm{CO}_{2}$, TAlk, and $\mathrm{pH}$ ) at each crossover against the density referenced to $4000 \mathrm{~dB}, \sigma_{4} . \sigma_{4}$ was calculated from conductivity-temperature-depth sensor (CTD) salinity, CTD temperature, and pressure with the algorithms of Millero and Poisson (1981). When pressure was not included in the provided data set, the algorithms of Saunders and Fofonoff (1976) were used to calculate it from depth. A commercial plotting program, KaleidaGraph, was then used to create plots. Within each plot, an expanded area representing deep-water values was then selected (typically $\sigma_{4} \approx 45.5-45.9$ ) and was plotted separately (Fig. 5). A second-order polynomial fit of the relevant carbon system parameter vs $\sigma_{4}$ was determined for this limited $\sigma_{4}$ range for each of the stations included in the crossover. For many of the crossovers, a strong curvature of DIC or TAlk vs density in the bottom waters complicated the curve-fitting analysis. Thus, the deepest water (Antarctic bottom water) often was not included in the regression. For high southern latitude crossovers, the inorganic carbon parameters were plotted against depth because the water masses south of $40^{\circ} \mathrm{S}$ have a very narrow density range.

Table 4 provides a summary of the derived constants $M_{0}, M_{1}, M_{2}$, and $r^{2}$ from the polynomial $X=M_{0}+M_{1}\left(\sigma_{4}\right)+M_{2}\left(\sigma_{4}\right)^{2}$ curve-fitting routine for each station profile, where $X$ is a value for DIC, TAlk, $f \mathrm{CO}_{2}$, or $\mathrm{pH}$. The correlation coefficient $r^{2}$ indicates the goodness of fit and often is a good indicator of precision of the data for a particular station. The calculated curve for each station in each crossover analysis was divided into ten evenly spaced $\sigma_{4}$ intervals, on average, 0.04 units apart, over the data range $\left(\sigma_{4} \approx 45.5-45.9\right)$. The value of $X$ was calculated for each point in the interval from the derived $M_{0}, M_{1}$, and $M_{2}$ for each of the stations. In all cases, the data bracketed the $\sigma_{4}$ interval. The average difference between station profiles was then determined and was used as the calculated offset in Table 4 . The standard deviation of the difference of the ten points indicated whether the offset values were systematic or scattered around the mean. As a convention, the calculated difference is always the value for a crossover station being subtracted from the first cruise/station of that crossover listed in Table 4 . A search radius of $1^{\circ}(\approx 100 \mathrm{~km})$ sometimes included more than one station from a given cruise. This situation offered the opportunity to assess offsets of data for adjacent stations for a particular cruise as well as 


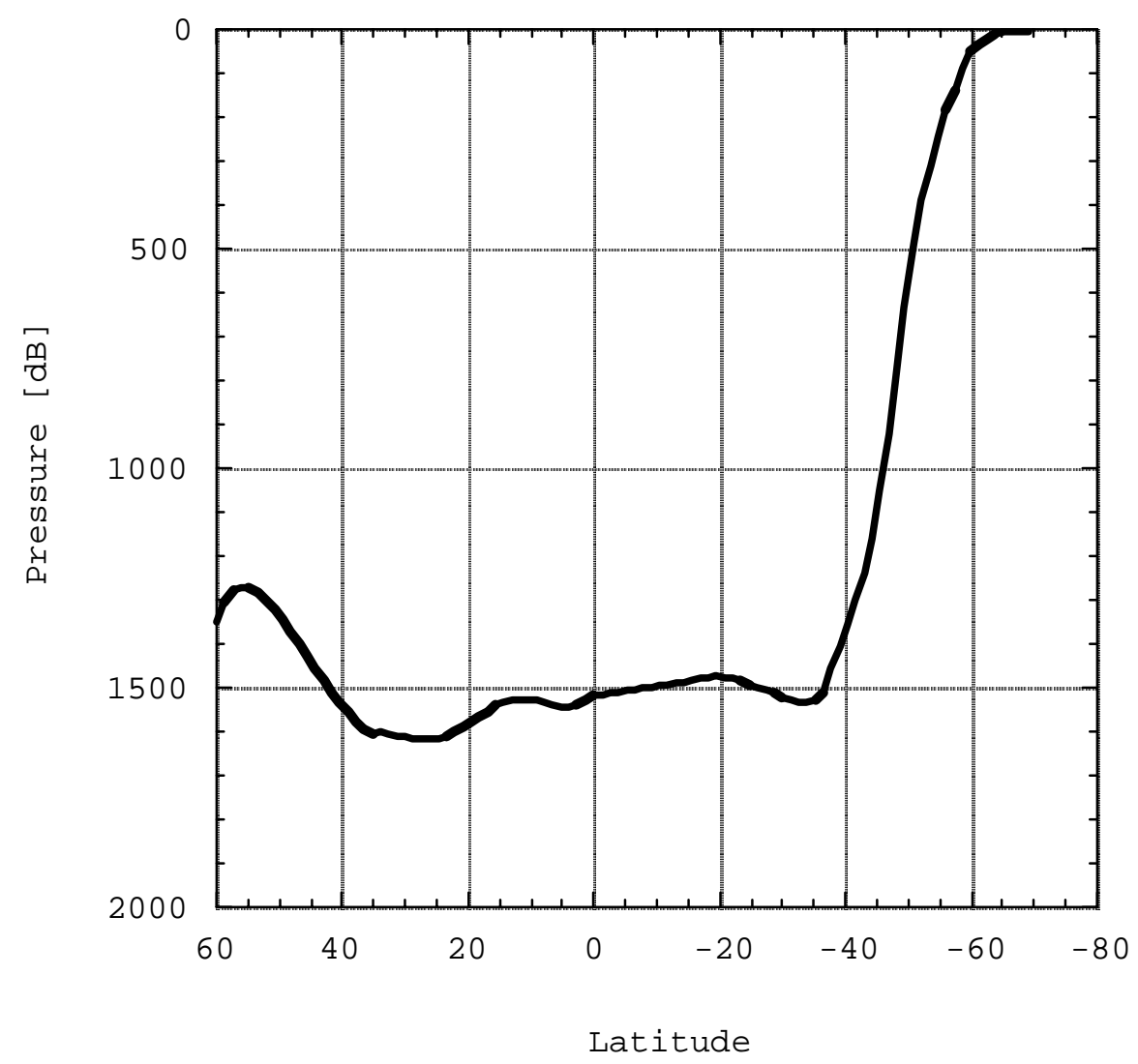

Fig. 5. Depth of isopycnal $45.5\left(\sigma_{4}\right)$ in the Atlantic Ocean based on cruises A16N, A16S, and A23.

differences between cruises. Table 5 contains information similar to Table 4, but it is ordered according to the cruise. This table contains an average of the means of the crossovers listed for each cruise and is useful for determining whether parameters on a particular cruise show consistent offsets. Plots of the crossovers can be found on the following website: http://www.aoml.noaa.gov/ocd/oaces/atlantic_synthesis.html.

\subsection{The Regional Multiple-Parameter Linear Regression Method for Checking for Offsets in DIC and TAlk}

A regional MLR was applied to corroborate any offsets in the crossover comparisons of DIC and TAlk data. The regional MLR was performed to determine whether DIC and TAlk data for particular cruises were consistent in a regional context. For this check, a somewhat subjective assessment was made to determine which cruises to use as controls to create the MLR and which to use as unknowns. In general, the unknowns had larger offsets in the crossover analyses and/or had more scatter in the data. Several iterations were performed with different subsets of cruises used as controls to determine the coefficients. This was done to ensure consistency in cruise data 
Table 4. Summary of crossover analysis results by location ${ }^{a}$

\begin{tabular}{|c|c|c|c|c|c|c|c|c|c|c|c|c|c|c|}
\hline \multirow{2}{*}{ Location } & \multirow{2}{*}{ Cruise } & \multirow{2}{*}{ Station } & \multicolumn{3}{|c|}{ Dissolved inorganic carbon } & \multicolumn{2}{|c|}{ Total alkalinity } & \multicolumn{4}{|c|}{ pH } & \multicolumn{3}{|c|}{$\mathrm{CO}_{2}$ fugacity } \\
\hline & & & $\mathbf{A v e}^{b}$ & StDev $^{c}$ & $\mathbf{R}^{2 d}$ & Ave & StDev & $\mathbf{R}^{2}$ & Ave & StDev & $\mathbf{R}^{2}$ & Ave & StDev & $\mathbf{R}^{2}$ \\
\hline \multirow[t]{3}{*}{$66^{\circ} \mathrm{W}, 24.2^{\circ} \mathrm{N}$} & A22 & 42 & & & 0.753 & & & 0.767 & & & 0.611 & & & \\
\hline & A22 & 44 & -1.9 & 1.1 & 0.804 & -1.4 & 2.4 & 0.892 & -0.0015 & 0.0031 & 0.730 & & & \\
\hline & $\mathrm{A} 05$ & 84 & -3.4 & 3.1 & 1.000 & -2.1 & 4.7 & 0.892 & 0.0383 & 0.0113 & 0.364 & & & \\
\hline \multirow[t]{4}{*}{$66^{\circ} \mathrm{W}, 24.2^{\circ} \mathrm{N}$} & A22 & 42 & & & 0.753 & & & 0.767 & & & 0.611 & & & \\
\hline & A22 & 44 & -0.9 & 2.0 & 0.804 & -1.4 & 2.4 & 0.892 & -0.0016 & 0.0031 & 0.730 & & & 0.729 \\
\hline & A05R & 85 & -3.4 & 4.6 & 0.714 & -0.3 & 3.0 & 0.870 & 0.0119 & 0.0012 & 0.625 & 6.8 & 3.6 & 0.280 \\
\hline & A05R & 86 & -1.5 & 0.4 & 0.909 & 9.0 & 10.4 & 1.000 & 0.0148 & 0.0022 & 0.708 & 7.0 & 4.0 & 0.952 \\
\hline \multirow[t]{7}{*}{$55^{\circ} \mathrm{W}, \mathbf{5 3 . 4}^{\circ} \mathrm{N}$} & A01W & 3 & & & 0.916 & & & 0.922 & & & & & & \\
\hline & $\mathrm{A} 01 \mathrm{~W}$ & 4 & -0.7 & 0.3 & 1.000 & -1.5 & 7.9 & 1.000 & & & & & & \\
\hline & $\mathrm{A} 01 \mathrm{~W}$ & 5 & -1.0 & 4.1 & 0.428 & -3.3 & 3.9 & 0.990 & & & & & & \\
\hline & A01WR & 26 & -7.93 & 2.95 & 0.961 & -29.9 & 9.9 & 0.736 & & & & & & \\
\hline & A01WR & 28 & -3.15 & 3.5 & 0.864 & -27.5 & 7.1 & 0.770 & & & & & & \\
\hline & A01WR & 30 & 1.15 & 2.02 & 1.000 & -19.9 & 5.2 & 1.000 & & & & & & \\
\hline & A01WR & 32 & 1.78 & 0.34 & 0.880 & -26.3 & 13.3 & 0.753 & & & & & & \\
\hline \multirow[t]{4}{*}{$52.3^{\circ} \mathrm{W}, 24.2^{\circ} \mathrm{N}$} & A20 & 47 & & & 0.984 & & & 0.955 & & & 0.915 & & & \\
\hline & A 20 & 48 & -0.7 & 0.1 & 0.979 & 0.5 & 0.8 & 0.965 & -0.0008 & 0.0020 & 0.852 & & & \\
\hline & A05 & 62 & -0.7 & 2.3 & 0.999 & -3.5 & 7.0 & 1.000 & -0.0016 & 0.0059 & 0.999 & & & \\
\hline & A05 & 64 & -4.5 & 5.9 & 1.000 & -4.4 & 7.7 & 1.000 & 0.0051 & 0.0371 & 0.200 & & & \\
\hline \multirow[t]{4}{*}{$52.3^{\circ} \mathrm{W}, 24.2^{\circ} \mathrm{N}$} & A20 & 47 & & & 0.971 & & & 0.976 & & & 0.908 & & & \\
\hline & A20 & 48 & -0.7 & 1.4 & 0.979 & 0.6 & 0.7 & 0.969 & -0.0004 & 0.0020 & 0.869 & & & \\
\hline & A05R & 66 & -2.5 & 2.8 & 0.886 & -4.5 & 1.4 & 0.975 & 0.0130 & 0.0003 & 0.789 & & & \\
\hline & A05R & 67 & -5.7 & 1.0 & 0.975 & -6.9 & 3.9 & 0.992 & 0.0123 & 0.0009 & 0.880 & & & \\
\hline \multirow[t]{4}{*}{$50^{\circ} \mathrm{W}, \mathbf{4 3 . 5}^{\circ} \mathrm{N}$} & A20 & 8 & & & 0.903 & & & 0.751 & & & & & & \\
\hline & $\mathrm{A} 20$ & 10 & -3.9 & 5.0 & 0.287 & -10.9 & 11.2 & 0.176 & & & & & & \\
\hline & $\mathrm{A} 02$ & 334 & 2.7 & 0.9 & 0.948 & -11.4 & 13.9 & 0.827 & & & & & & \\
\hline & $\mathrm{A} 02$ & 336 & -6.9 & 9.8 & 0.936 & & & & & & & & & \\
\hline \multirow[t]{2}{*}{$47.2^{\circ} \mathrm{W}, 60.2^{\circ} \mathrm{S}$} & A12 & 122 & & & 0.963 & & & & & & & & & \\
\hline & A12B & 640 & 1.3 & 0.5 & 0.524 & & & & & & & & & \\
\hline \multirow[t]{4}{*}{$44.5^{\circ} \mathrm{W}, 7.4^{\circ} \mathrm{N}$} & $A 06$ & 140 & & & 0.786 & & & 0.502 & & & 0.970 & & & \\
\hline & A 17 & 200 & & & & & & & -0.0509 & 0.0487 & 0.821 & & & \\
\hline & A 17 & 201 & 5.4 & 14.9 & 0.832 & 2.2 & 11.8 & 0.933 & -0.0477 & 0.0497 & 0.615 & & & \\
\hline & A17 & 202 & & & & & & & -0.0512 & 0.0456 & 0.848 & & & \\
\hline \multirow[t]{3}{*}{$44^{\circ} \mathrm{W}, 64^{\circ} \mathrm{S}$} & A12BR & 94 & & & 0.933 & & & & & & & & & \\
\hline & A12B & 630 & 0.9 & 0.4 & 0.960 & & & & & & & & & \\
\hline & A12B & 631 & 3.6 & 2.9 & 0.977 & & & & & & & & & \\
\hline
\end{tabular}




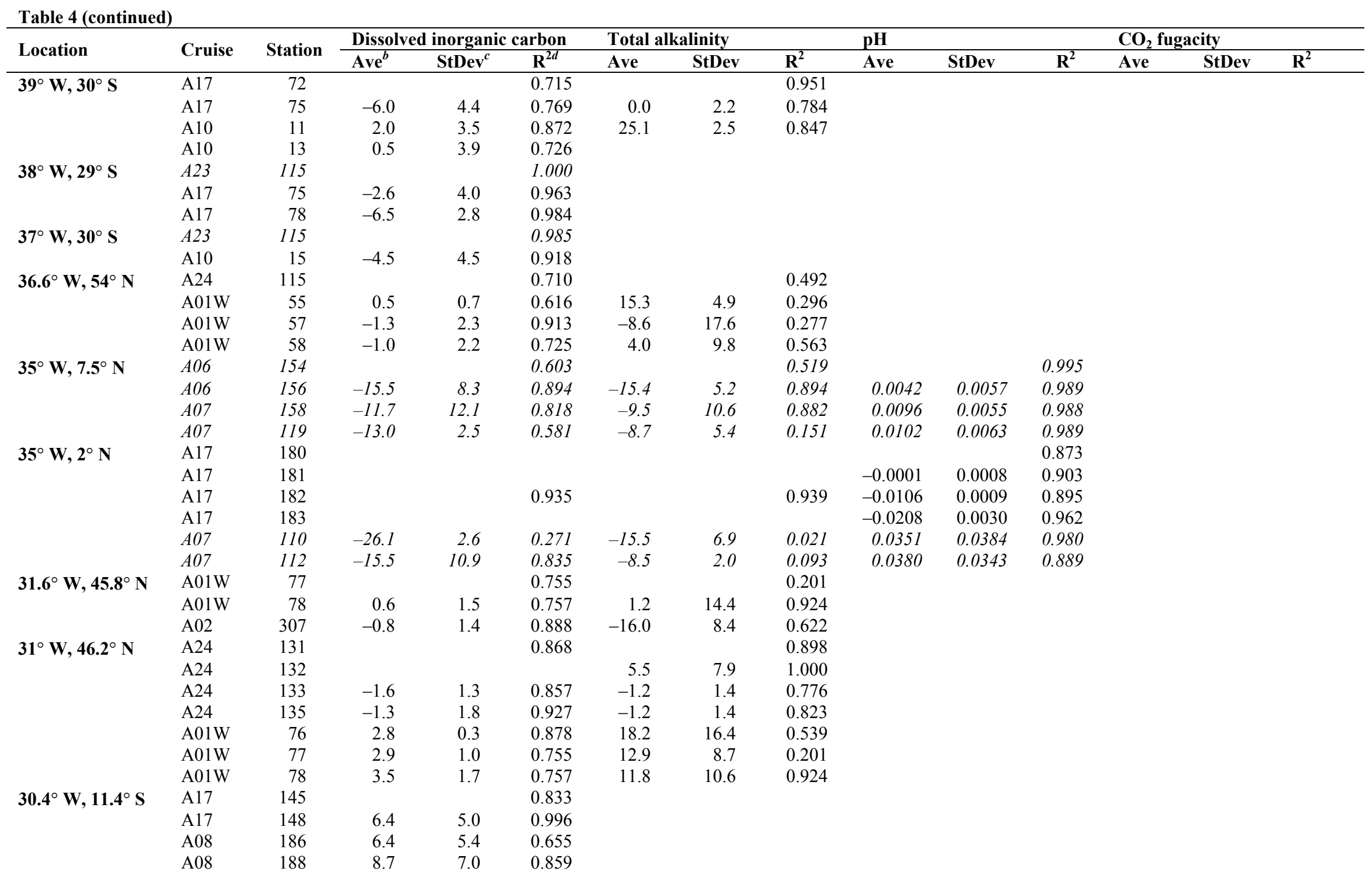




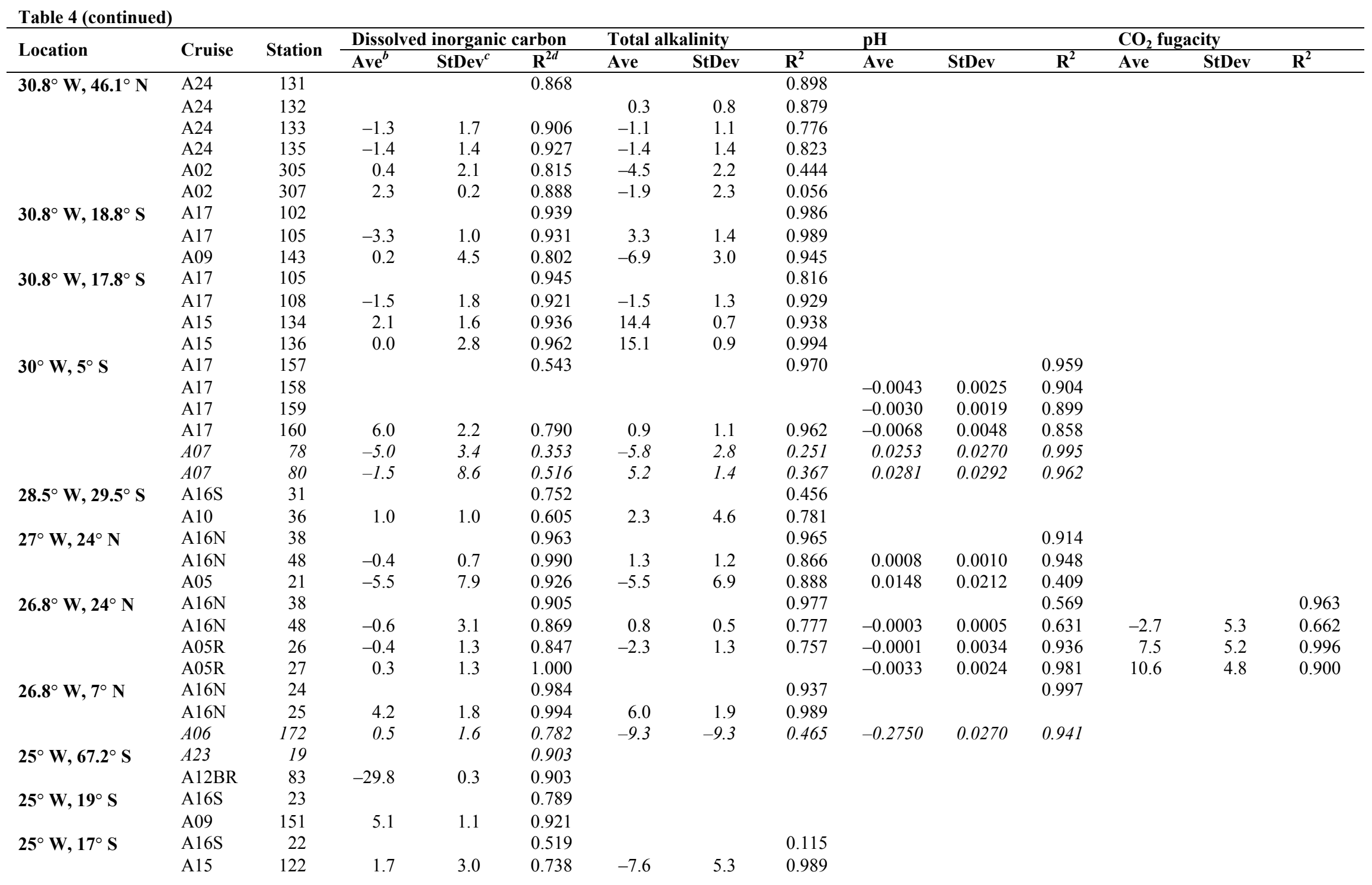




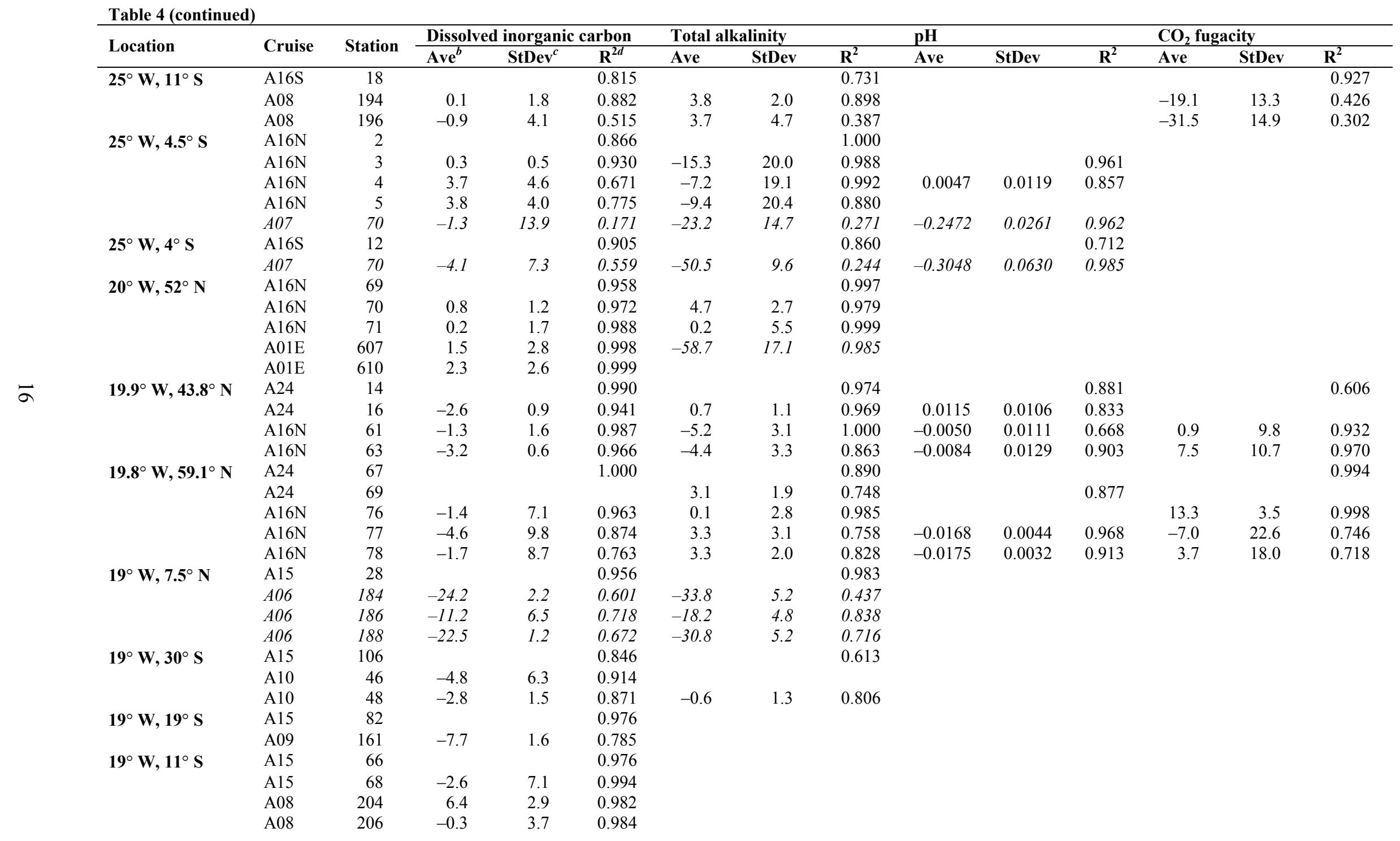




\begin{tabular}{|c|c|c|c|c|c|c|c|c|c|c|c|c|c|c|}
\hline \multirow{2}{*}{ Location } & \multirow{2}{*}{ Cruise } & \multirow{2}{*}{ Station } & \multicolumn{3}{|c|}{ Dissolved inorganic carbon } & \multicolumn{2}{|c|}{ Total alkalinity } & \multicolumn{3}{|c|}{ pH } & \multicolumn{4}{|c|}{$\mathrm{CO}_{2}$ fugacity } \\
\hline & & & $A^{b} e^{b}$ & StDev $^{c}$ & $\mathbf{R}^{2 d}$ & Ave & StDev & $\mathbf{R}^{2}$ & Ave & StDev & $\mathbf{R}^{2}$ & Ave & StDev & $\mathbf{R}^{2}$ \\
\hline \multirow[t]{4}{*}{$11.2^{\circ} \mathrm{W}, 49.2^{\circ} \mathrm{N}$} & A24 & 32 & & & 0.984 & & & 0.923 & & & & & & \\
\hline & A24 & 33 & 8.2 & 9.3 & 0.999 & 1.4 & 0.2 & 0.878 & & & & & & \\
\hline & A24 & 34 & 12.3 & 15.5 & 0.997 & 0.4 & 1.2 & 0.761 & & & & & & \\
\hline & A02 & 282 & 0.1 & 7.6 & 0.996 & -4.3 & 2.4 & 0.934 & & & & & & \\
\hline \multirow[t]{4}{*}{$9^{\circ} \mathrm{W}, 11.5^{\circ} \mathrm{S}$} & A14 & 37 & & & 0.995 & & & 0.995 & & & & & & \\
\hline & A14 & 40 & -1.1 & 1.4 & 0.961 & 0.0 & 2.0 & 0.992 & & & & & & \\
\hline & A08 & 226 & 0.2 & 0.6 & 0.991 & 12.1 & 0.7 & 0.977 & & & & & & \\
\hline & A08 & 228 & 0.4 & 0.9 & 0.994 & 11.0 & 1.8 & 0.984 & & & & & & \\
\hline \multirow[t]{3}{*}{$9^{\circ} \mathrm{W}, 19^{\circ} \mathrm{S}$} & A14 & 52 & & & 0.884 & & & 0.988 & & & & & & \\
\hline & A14 & 55 & -1.7 & 1.3 & 0.940 & -2.7 & 1.3 & 0.959 & & & & & & \\
\hline & A09 & 187 & -1.3 & 2.2 & 0.996 & 2.7 & 1.7 & 0.130 & & & & & & \\
\hline \multirow[t]{2}{*}{$9^{\circ} \mathbf{W}, 30^{\circ} \mathrm{S}$} & A14 & 76 & & & 0.925 & & & & & & & & & \\
\hline & $\mathrm{A} 10$ & 62 & 4.9 & 2.4 & 0.991 & & & & & & & & & \\
\hline \multirow[t]{8}{*}{$8^{\circ} \mathrm{W}, 4.5^{\circ} \mathrm{S}$} & A14 & 22 & & & 0.968 & & & 0.966 & & & 0.929 & & & \\
\hline & A14 & 23 & & & & & & & 0.0012 & 0.0021 & 0.883 & & & \\
\hline & A14 & 24 & & & & & & & 0.0023 & 0.0021 & 0.753 & & & \\
\hline & A14 & 25 & -3.6 & 0.4 & 0.971 & -2.4 & 0.8 & 0.985 & 0.0045 & 0.0005 & 0.793 & & & \\
\hline & A14 & 26 & & & & & & & 0.0041 & 0.0021 & 0.888 & & & \\
\hline & A14 & 27 & & & & & & & 0.0060 & 0.010 & 0.924 & & & \\
\hline & A07 & 38 & -26.4 & 5.8 & 0.652 & -26.5 & 5.7 & 0.006 & 0.0317 & 0.0320 & 0.943 & & & \\
\hline & $A 07$ & 40 & -23.0 & 8.3 & 0.877 & -23.3 & 7.1 & 0.187 & 0.0247 & 0.0306 & 0.943 & & & \\
\hline \multirow[t]{2}{*}{$0^{\circ}, 58.5^{\circ} \mathrm{S}$} & A12BR & 31 & & & 0.958 & & & & & & & & & \\
\hline & A12 & 149 & 1.7 & 0.8 & 0.986 & & & & & & & & & \\
\hline \multirow[t]{3}{*}{$0^{\circ}, 57^{\circ} \mathrm{S}$} & A12 & 151 & & & 0.990 & & & & & & & & & \\
\hline & $\mathrm{A} 12 \mathrm{~B}$ & 577 & -1.7 & 1.1 & 0.936 & & & & & & & & & \\
\hline & A12B & 578 & 0.7 & 1.3 & 0.950 & & & & & & & & & \\
\hline \multirow[t]{4}{*}{$0^{\circ}, 55.5^{\circ} \mathrm{S}$} & A12BR & 35 & & & & & & & & & & & & \\
\hline & A12BR & 36 & & & 0.726 & & & & & & & & & \\
\hline & A12BR & 37 & 0.7 & 1.4 & 0.980 & & & & & & & & & \\
\hline & A12 & 153 & 2.3 & 0.7 & 0.963 & & & & & & & & & \\
\hline \multirow[t]{4}{*}{$4.8^{\circ} \mathrm{E}, 4.7^{\circ} \mathrm{S}$} & A13 & 210 & & & 0.960 & & & & & & & & & \\
\hline & $A 07$ & 15 & 3.8 & 7.8 & 0.858 & & & & & & & & & \\
\hline & $A 07$ & 17 & 11.9 & 1.7 & 0.748 & & & & & & & & & \\
\hline & $A 07$ & 18 & -5.9 & 9.4 & 0.351 & & & & & & & & & \\
\hline
\end{tabular}


Table 4 (continued)

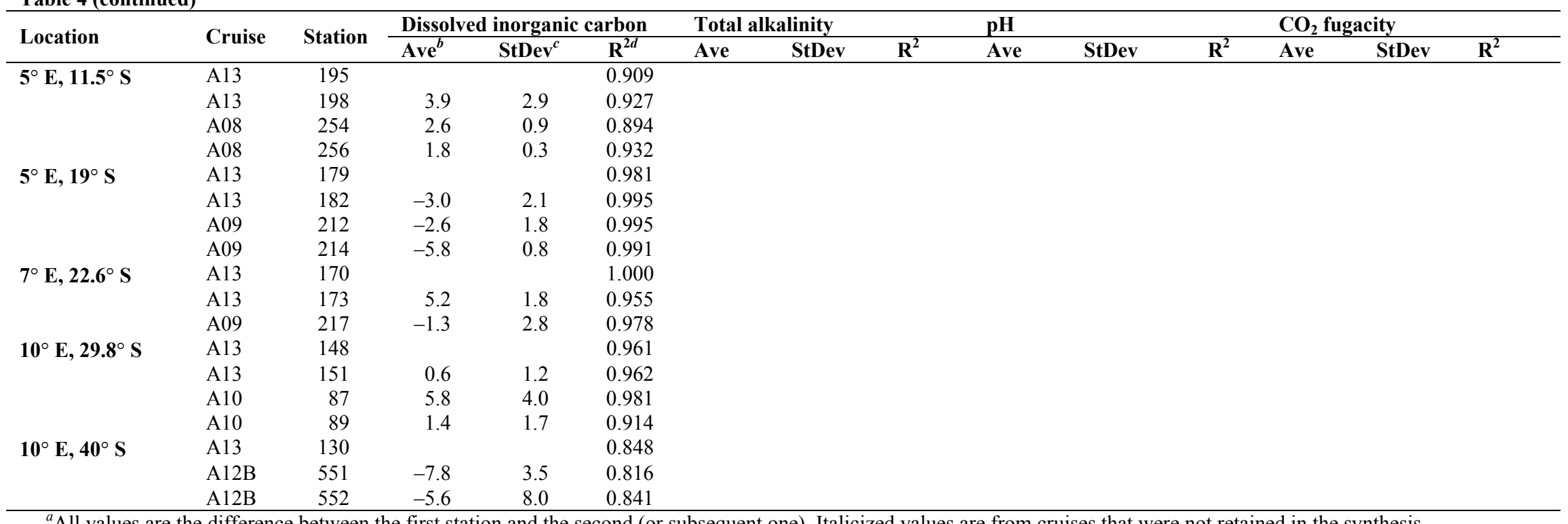

${ }^{a}$ All values are the difference between the first station and the second (or subsequent one). Italicized values are from cruises that were not retained in the synthesis.

${ }^{b}$ Ave $=$ Average difference of 10 equally spaced points on the two least squares second-order polynomial lines of property versus $\sigma_{4}$ between nominally $\sigma_{4}=45.5$ and 45.9 . The average difference between stations, "Ave," for the same cruise is an indication of the station to station variability in data.

${ }^{c} \mathrm{StDev}=$ Standard deviation of the average difference of ten equally spaced points on the two lines.

${ }^{d} \mathrm{R}^{2}=$ Goodness of fit for the line. An $\mathrm{R}^{2}$ of one indicates that only three points were in the selected range, which yields a perfect fit for the second order polynomial. 
Table 5. Summary of crossover analysis results by cruise $\mathrm{e}^{a, b}$

\begin{tabular}{|c|c|c|c|c|c|c|c|c|c|c|}
\hline \multirow{2}{*}{ Cruise } & \multirow{2}{*}{ Crossover } & \multirow[t]{2}{*}{ Location } & \multicolumn{2}{|c|}{ Dissolved inorganic carbon } & \multicolumn{2}{|c|}{ Total alkalinity } & \multicolumn{2}{|l|}{ pH } & \multicolumn{2}{|c|}{$\mathrm{CO}_{2}$ fugacity } \\
\hline & & & Ave & StDev & Ave & StDev & Ave & St Dev & Ave & St Dev \\
\hline$\overline{\text { A01E }}$ & $\mathrm{A} 16 \mathrm{~N}$ & $20^{\circ} \mathrm{W}, 52^{\circ} \mathrm{N}$ & -1.89 & 0.53 & 58.69 & 17.14 & & & & \\
\hline \multirow[t]{4}{*}{ A01W } & A24 & $36.6^{\circ} \mathrm{W}, 54^{\circ} \mathrm{N}$ & 0.62 & 0.95 & -3.58 & 11.96 & & & & \\
\hline & A24 & $31^{\circ} \mathrm{W}, 46.2^{\circ} \mathrm{N}$ & -3.07 & 0.36 & -14.31 & 3.45 & & & & \\
\hline & A01WR & $55^{\circ} \mathrm{W}, 53.4^{\circ} \mathrm{N}$ & -2.04 & 4.50 & -25.90 & 4.26 & & & & \\
\hline & A02 & $31.6^{\circ} \mathrm{W}, 45.8^{\circ} \mathrm{N}$ & -0.81 & 1.43 & -16.02 & 8.44 & & & & \\
\hline A01WR & $\mathrm{A} 01 \mathrm{~W}$ & $55^{\circ} \mathrm{W}, 53.4^{\circ} \mathrm{N}$ & 2.04 & 4.5 & 25.90 & 4.26 & & & & \\
\hline \multirow[t]{4}{*}{ A02 } & $\mathrm{A} 20$ & $50^{\circ} \mathrm{W}, 43.5^{\circ} \mathrm{N}$ & 2.08 & 6.77 & 11.39 & 13.87 & & & & \\
\hline & $\mathrm{A} 01 \mathrm{~W}$ & $31.6^{\circ} \mathrm{W}, 45.8^{\circ} \mathrm{N}$ & 0.81 & 1.43 & 16.02 & 8.44 & & & & \\
\hline & A24 & $30.8^{\circ} \mathrm{W}, 46.1^{\circ} \mathrm{N}$ & -1.33 & 1.34 & 3.18 & 1.84 & & & & \\
\hline & $\mathrm{A} 24$ & $11.2^{\circ} \mathrm{W}, 49.2^{\circ} \mathrm{N}$ & -0.06 & 7.6 & 4.28 & 2.39 & & & & \\
\hline \multirow[t]{3}{*}{ A05 } & A22 & $66^{\circ} \mathrm{W}, 24.2^{\circ} \mathrm{N}$ & 3.42 & 3.1 & 2.13 & 4.69 & -0.04 & 0.01 & & \\
\hline & $\mathrm{A} 20$ & $52.3^{\circ} \mathrm{W}, 24.2^{\circ} \mathrm{N}$ & 2.6 & 2.63 & 3.95 & 0.64 & -0.002 & 0.01 & & \\
\hline & $\mathrm{A} 16 \mathrm{~N}$ & $27^{\circ} \mathrm{W}, 24^{\circ} \mathrm{N}$ & 5.52 & 7.92 & 5.55 & 6.91 & -0.01 & 0.02 & & \\
\hline \multirow[t]{3}{*}{ A05R } & A22 & $66^{\circ} \mathrm{W}, 24.2^{\circ} \mathrm{N}$ & 2.46 & 1.34 & -4.33 & 6.57 & -0.01 & 0 & -6.92 & 0.11 \\
\hline & $\mathrm{A} 20$ & $52.3^{\circ} \mathrm{W}, 24.2^{\circ} \mathrm{N}$ & 4.1 & 2.26 & 5.71 & 1.66 & -0.01 & 0 & & \\
\hline & $\mathrm{A} 16 \mathrm{~N}$ & $26.8^{\circ} \mathrm{W}, 24^{\circ} \mathrm{N}$ & 0.05 & 0.55 & 2.3 & 1.28 & 0.002 & 0 & -9.05 & 2.16 \\
\hline \multirow[t]{4}{*}{ A06 } & $A 17$ & $44.5^{\circ} \mathrm{W}, 7.4^{\circ} \mathrm{N}$ & 5.38 & 15 & 2.21 & 11.81 & -0.05 & 0.002 & & \\
\hline & $A 07$ & $35^{\circ} \mathrm{W}, 7.5^{\circ} \mathrm{N}$ & -12.32 & 0.9 & -8.67 & 5.43 & 0.01 & 0.006 & & \\
\hline & $A 16 N$ & $26.8^{\circ} \mathrm{W}, 7^{\circ} \mathrm{N}$ & -0.54 & 1.6 & 9.30 & 1.29 & 0.28 & 0.030 & & \\
\hline & $A 15$ & $19^{\circ} \mathrm{W}, 7.5^{\circ} \mathrm{N}$ & 19.27 & 7.07 & 27.60 & 8.28 & & & & \\
\hline \multirow[t]{7}{*}{ A07 } & $A 06$ & $35^{\circ} \mathrm{W}, 7.5^{\circ} \mathrm{S}$ & 12.32 & 0.9 & 8.67 & 5.43 & 0.01 & 0.0006 & & \\
\hline & $A 13$ & $4.8^{\circ} \mathrm{E} 4.7^{\circ} \mathrm{S}$ & -3.27 & 8.9 & & & & & & \\
\hline & $A 14$ & $8^{\circ} \mathrm{W}, 4.5^{\circ} \mathrm{S}$ & 24.68 & 2.4 & 24.93 & 2.25 & -0.06 & 0.005 & & \\
\hline & $A 17$ & $35^{\circ} \mathrm{W}, 2^{\circ} \mathrm{N}$ & 20.77 & 7.5 & 12.02 & 4.92 & -0.04 & 0.002 & & \\
\hline & $A 17$ & $30^{\circ} \mathrm{W}, 5^{\circ} \mathrm{S}$ & 3.25 & 2.5 & 0.34 & 7.78 & -0.03 & 0.002 & & \\
\hline & $A 16 S$ & $25^{\circ} \mathrm{W}, 4^{\circ} \mathrm{S}$ & 4.15 & 7.3 & & & & & & \\
\hline & $A 16 N$ & $25^{\circ} \mathrm{W}, 4.5^{\circ} \mathrm{S}$ & 1.28 & 14 & 23.22 & 14.73 & 0.25 & 0.03 & & \\
\hline \multirow[t]{5}{*}{ A08 } & A17 & $30.4^{\circ} \mathrm{W}, 11.4^{\circ} \mathrm{S}$ & -7.50 & 1.63 & & & & & & \\
\hline & A16S & $25^{\circ} \mathrm{W}, 11^{\circ} \mathrm{S}$ & 0.37 & 0.69 & -3.75 & 0.07 & & & 25.33 & 8.80 \\
\hline & A13 & $5^{\circ} \mathrm{E} 11.5^{\circ} \mathrm{S}$ & -2.21 & 0.57 & & & & & & \\
\hline & A14 & $9^{\circ} \mathrm{W}, 11.5^{\circ} \mathrm{S}$ & -0.34 & 0.13 & -11.53 & 0.82 & & & & \\
\hline & A15 & $19^{\circ} \mathrm{W}, 11^{\circ} \mathrm{S}$ & -3.05 & 4.69 & & & & & & \\
\hline
\end{tabular}




\begin{tabular}{|c|c|c|c|c|c|c|c|c|c|c|}
\hline \multirow{2}{*}{ Cruise } & \multirow{2}{*}{ Crossover } & \multirow[t]{2}{*}{ Location } & \multicolumn{2}{|c|}{ Dissolved inorganic carbon } & \multicolumn{2}{|c|}{ Total alkalinity } & \multicolumn{2}{|l|}{ pH } & \multicolumn{2}{|c|}{$\mathrm{CO}_{2}$ fugacity } \\
\hline & & & Ave & StDev & Ave & StDev & Ave & St Dev & Ave & St Dev \\
\hline \multirow[t]{6}{*}{ A09 } & A17 & $30.8^{\circ} \mathrm{W}, 18.8^{\circ} \mathrm{S}$ & -0.18 & 4.53 & 6.95 & 3.01 & & & & \\
\hline & A13 & $5^{\circ} \mathrm{E} 19^{\circ} \mathrm{S}$ & 4.18 & 2.26 & & & & & & \\
\hline & A13 & $7^{\circ} \mathrm{E} 22.6^{\circ} \mathrm{S}$ & 1.26 & 2.82 & & & & & & \\
\hline & A14 & $9^{\circ} \mathrm{W}, 19^{\circ} \mathrm{S}$ & 1.34 & 2.21 & & & & & & \\
\hline & A16S & $25^{\circ} \mathrm{W}, 19^{\circ} \mathrm{S}$ & -5.11 & 1.13 & & & & & & \\
\hline & A15 & $19^{\circ} \mathrm{W}, 19^{\circ} \mathrm{S}$ & 7.69 & 1.64 & & & & & & \\
\hline \multirow[t]{5}{*}{ A10 } & A 17 & $39^{\circ} \mathrm{W}, 30^{\circ} \mathrm{S}$ & -1.23 & 1.04 & -25.1 & 2.47 & & & & \\
\hline & A14 & $9^{\circ} \mathrm{W}, 30^{\circ} \mathrm{S}$ & -4.90 & 2.43 & & & & & & \\
\hline & A16S & $28.5^{\circ} \mathrm{W}, 29.5^{\circ} \mathrm{S}$ & -1.04 & 1.03 & -2.27 & 4.58 & & & & \\
\hline & $A 23$ & $37^{\circ} \mathrm{W}, 30^{\circ} \mathrm{S}$ & 4.51 & 4.53 & & & & & & \\
\hline & A15 & $19^{\circ} \mathrm{W}, 30^{\circ} \mathrm{S}$ & 3.84 & 1.42 & 0.56 & 1.29 & & & & \\
\hline \multirow[t]{4}{*}{ A12 } & $\mathrm{A} 12 \mathrm{~B}$ & $0^{\circ} 57^{\circ} \mathrm{S}$ & -0.46 & 1.70 & & & & & & \\
\hline & A12B & $47.2^{\circ} \mathrm{W}, 60.2^{\circ} \mathrm{S}$ & 1.34 & 0.5 & & & & & & \\
\hline & A12BR & $0^{\circ} 58.5^{\circ} \mathrm{S}$ & -1.70 & 0.81 & & & & & & \\
\hline & A12BR & $0^{\circ} 55.5^{\circ} \mathrm{S}$ & -2.31 & 0.65 & & & & & & \\
\hline \multirow[t]{3}{*}{ A12B } & A12BR & $44^{\circ} \mathrm{W}, 64^{\circ} \mathrm{S}$ & -2.25 & 1.86 & & & & & & \\
\hline & A12 & $47.2^{\circ} \mathrm{W}, 60.2^{\circ} \mathrm{S}$ & -1.34 & 0.50 & & & & & & \\
\hline & A13 & $10^{\circ} \mathrm{E} 40^{\circ} \mathrm{S}$ & 6.71 & 1.56 & & & & & & \\
\hline \multirow[t]{4}{*}{ A12BR } & $\mathrm{A} 12 \mathrm{~B}$ & $44^{\circ} \mathrm{W}, 64^{\circ} \mathrm{S}$ & 2.25 & 1.86 & & & & & & \\
\hline & A23 & $25^{\circ} \mathrm{W}, 67.2^{\circ} \mathrm{S}$ & 29.78 & 0.30 & & & & & & \\
\hline & A12 & $0^{\circ} 58.5^{\circ} \mathrm{S}$ & 1.70 & 0.81 & & & & & & \\
\hline & A12 & $0^{\circ} 55.5^{\circ} \mathrm{S}$ & 2.31 & 0.65 & & & & & & \\
\hline \multirow[t]{6}{*}{ A13 } & A07 & $4.8^{\circ} \mathrm{E} 4.7^{\circ} \mathrm{S}$ & 3.27 & 8.9 & & & & & & \\
\hline & A08 & $5^{\circ} \mathrm{E} 11.5^{\circ} \mathrm{S}$ & 2.21 & 0.57 & & & & & & \\
\hline & A09 & $5^{\circ} \mathrm{E} 19^{\circ} \mathrm{S}$ & -4.18 & 2.26 & & & & & & \\
\hline & A09 & $7^{\circ} \mathrm{E} 22.6^{\circ} \mathrm{S}$ & -1.26 & 2.82 & & & & & & \\
\hline & A 10 & $10^{\circ} \mathrm{E} 29.8^{\circ} \mathrm{S}$ & 3.64 & 3.13 & & & & & & \\
\hline & A12B & $10^{\circ} \mathrm{E} 40^{\circ} \mathrm{S}$ & -6.71 & 1.56 & & & & & & \\
\hline \multirow[t]{4}{*}{ A14 } & $A 07$ & $8^{\circ} \mathrm{W}, 4.5^{\circ} \mathrm{S}$ & -24.68 & 2.4 & -24.93 & 2.25 & 0.03 & 0.005 & & \\
\hline & A08 & $9^{\circ} \mathrm{W}, 11.5^{\circ} \mathrm{S}$ & 0.34 & 0.13 & 11.53 & 0.82 & & & & \\
\hline & A09 & $9^{\circ} \mathrm{W}, 19^{\circ} \mathrm{S}$ & -1.34 & 2.21 & 2.72 & 1.74 & & & & \\
\hline & A 10 & $9^{\circ} \mathrm{W}, 30^{\circ} \mathrm{S}$ & 4.9 & 2.43 & & & & & & \\
\hline
\end{tabular}




\begin{tabular}{|c|c|c|c|c|c|c|c|c|c|c|}
\hline \multirow{2}{*}{ Cruise } & \multirow{2}{*}{ Crossover } & \multirow[t]{2}{*}{ Location } & \multicolumn{2}{|c|}{ Dissolved inorganic carbon } & \multicolumn{2}{|c|}{ Total alkalinity } & \multicolumn{2}{|l|}{ pH } & \multicolumn{2}{|c|}{$\mathrm{CO}_{2}$ fugacity } \\
\hline & & & Ave & StDev & Ave & StDev & Ave & St Dev & Ave & St Dev \\
\hline \multirow[t]{6}{*}{$\mathbf{A 1 5}$} & A17 & $30.8^{\circ} \mathrm{W}, 17.8^{\circ} \mathrm{S}$ & -1.05 & 1.47 & -14.74 & 0.49 & & & & \\
\hline & A16S & $25^{\circ} \mathrm{W}, 17^{\circ} \mathrm{S}$ & -1.68 & 2.97 & 7.56 & 5.31 & & & & \\
\hline & A10 & $19^{\circ} \mathrm{W}, 30^{\circ} \mathrm{S}$ & -3.84 & 1.42 & -0.56 & 1.29 & & & & \\
\hline & $A 06$ & $19^{\circ} \mathrm{W}, 7.5^{\circ} \mathrm{N}$ & -19.27 & 7.07 & -27.60 & 8.28 & & & & \\
\hline & A09 & $19^{\circ} \mathrm{W}, 19^{\circ} \mathrm{S}$ & -7.69 & 1.64 & & & & & & \\
\hline & A08 & $19^{\circ} \mathrm{W}, 11^{\circ} \mathrm{S}$ & 3.05 & 4.69 & & & & & & \\
\hline \multirow[t]{5}{*}{ A16S } & A10 & $28.5^{\circ} \mathrm{W}, 29.5^{\circ} \mathrm{S}$ & 1.04 & 1.03 & 2.27 & 4.58 & & & & \\
\hline & A09 & $25^{\circ} \mathrm{W}, 19^{\circ} \mathrm{S}$ & 5.11 & 1.13 & & & & & & \\
\hline & A 15 & $25^{\circ} \mathrm{W}, 17^{\circ} \mathrm{S}$ & 1.68 & 2.97 & -7.56 & 5.31 & & & & \\
\hline & A08 & $25^{\circ} \mathrm{W}, 11^{\circ} \mathrm{S}$ & -0.37 & 0.69 & 3.75 & 0.07 & & & -25.33 & 8.80 \\
\hline & $A 07$ & $25^{\circ} \mathrm{W}, 4^{\circ} \mathrm{S}$ & -4.15 & 7.3 & & & & & & \\
\hline \multirow[t]{6}{*}{ A16N } & A05 & $27^{\circ} \mathrm{W}, 24^{\circ} \mathrm{N}$ & -5.52 & 7.92 & -5.55 & 6.91 & 0.01 & 0.02 & & \\
\hline & A05R & $26.8^{\circ} \mathrm{W}, 24^{\circ} \mathrm{N}$ & -0.05 & 0.55 & -2.3 & 1.28 & -0.002 & 0 & 9.05 & 2.16 \\
\hline & $A 06$ & $26.8^{\circ} \mathrm{W}, 7^{\circ} \mathrm{N}$ & 0.54 & 1.6 & -9.30 & 1.29 & -0.28 & 0 & & \\
\hline & $A 07$ & $25^{\circ} \mathrm{W}, 4.5^{\circ} \mathrm{S}$ & -1.28 & 14 & -23.22 & 14.73 & -0.25 & 0 & & \\
\hline & $\mathrm{A} 01 \mathrm{E}$ & $20^{\circ} \mathrm{W}, 52^{\circ} \mathrm{N}$ & 1.89 & 0.53 & -58.69 & 17.14 & & & & \\
\hline & A24 & $19.9^{\circ} \mathrm{W}, 43.8^{\circ} \mathrm{N}$ & 2.21 & 1.34 & 4.78 & 0.57 & 0.007 & 0 & -4.2 & 4.72 \\
\hline \multirow[t]{8}{*}{ A17 } & $A 06$ & $44.5^{\circ} \mathrm{W}, 7.4^{\circ} \mathrm{N}$ & -5.38 & 15 & -2.21 & 11.81 & 0.05 & 0 & & \\
\hline & A10 & $39^{\circ} \mathrm{W}, 30^{\circ} \mathrm{S}$ & 1.23 & 1.04 & 25.1 & 2.47 & & & & \\
\hline & $A 07$ & $35^{\circ} \mathrm{W}, 2^{\circ} \mathrm{N}$ & -20.77 & 7.5 & -12.02 & 4.92 & 0.04 & 0 & & \\
\hline & $A 07$ & $30^{\circ} \mathrm{W}, 5^{\circ} \mathrm{S}$ & -3.25 & 2.5 & -0.34 & 7.78 & 0.03 & 0 & & \\
\hline & A08 & $30.4^{\circ} \mathrm{W}, 11.4^{\circ} \mathrm{S}$ & 7.5 & 1.63 & & & & & & \\
\hline & A09 & $30.8^{\circ} \mathrm{W}, 18.8^{\circ} \mathrm{S}$ & 0.18 & 4.53 & -6.95 & 3.01 & & & & \\
\hline & $A 23$ & $38^{\circ} \mathrm{W}, 29^{\circ} \mathrm{S}$ & 4.56 & 2.8 & & & & & & \\
\hline & A15 & $30.8^{\circ} \mathrm{W}, 17.8^{\circ} \mathrm{S}$ & 1.05 & 1.47 & 14.74 & 0.49 & & & & \\
\hline \multirow[t]{3}{*}{ A20 } & A05 & $52.3^{\circ} \mathrm{W}, 24.2^{\circ} \mathrm{N}$ & -2.6 & 2.63 & -3.95 & 0.64 & 0.002 & 0.01 & & \\
\hline & A05R & $52.3^{\circ} \mathrm{W}, 24.2^{\circ} \mathrm{N}$ & -4.1 & 2.26 & -5.71 & 1.66 & 0.01 & 0 & & \\
\hline & A02 & $50^{\circ} \mathrm{W}, 43.5^{\circ} \mathrm{N}$ & -2.08 & 6.77 & -11.39 & 13.87 & & & & \\
\hline \multirow[t]{2}{*}{ A22 } & A05 & $66^{\circ} \mathrm{W}, 24.2^{\circ} \mathrm{N}$ & -3.42 & 3.1 & -2.13 & 4.69 & 0.04 & 0.01 & & \\
\hline & A05R & $66^{\circ} \mathrm{W}, 24.2^{\circ} \mathrm{N}$ & -2.46 & 1.34 & 4.33 & 6.57 & 0.01 & 0 & 6.92 & 0.11 \\
\hline \multirow[t]{3}{*}{$\mathbf{A 2 3}$} & A17 & $38^{\circ} \mathrm{W}, 29^{\circ} \mathrm{S}$ & -4.56 & 2.8 & & & & & & \\
\hline & A10 & $37^{\circ} \mathrm{W}, 30^{\circ} \mathrm{S}$ & -4.51 & 4.54 & & & & & & \\
\hline & A12BR & $25^{\circ} \mathrm{W}, 67.2^{\circ} \mathrm{S}$ & -29.78 & 0.3 & & & & & & \\
\hline
\end{tabular}




\begin{tabular}{|c|c|c|c|c|c|c|c|c|c|c|}
\hline \multirow{2}{*}{ Cruise } & \multirow{2}{*}{ Crossover } & \multirow[t]{2}{*}{ Location } & \multicolumn{2}{|c|}{ Dissolved inorganic carbon } & \multicolumn{2}{|c|}{ Total alkalinity } & \multicolumn{2}{|l|}{ pH } & \multicolumn{2}{|c|}{$\mathrm{CO}_{2}$ fugacity } \\
\hline & & & Ave & StDev & Ave & StDev & Ave & St Dev & Ave & St Dev \\
\hline \multirow[t]{6}{*}{$\mathbf{A 2 4}$} & $\mathrm{A} 01 \mathrm{~W}$ & $36.6^{\circ} \mathrm{W}, 54^{\circ} \mathrm{N}$ & -0.62 & 0.95 & 3.58 & 11.96 & & & & \\
\hline & $\mathrm{A} 01 \mathrm{~W}$ & $31^{\circ} \mathrm{W}, 46.2^{\circ} \mathrm{N}$ & 3.07 & 0.36 & 14.31 & 3.45 & & & & \\
\hline & A02 & $30.8^{\circ} \mathrm{W}, 46.1^{\circ} \mathrm{N}$ & 1.33 & 1.34 & -3.18 & 1.84 & & & & \\
\hline & A02 & $11.2^{\circ} \mathrm{W}, 49.2^{\circ} \mathrm{N}$ & 0.06 & 7.6 & -4.28 & 2.39 & & & & \\
\hline & $\mathrm{A} 16 \mathrm{~N}$ & $19.9^{\circ} \mathrm{W}, 43.8^{\circ} \mathrm{N}$ & -2.21 & 1.34 & -4.78 & 0.57 & -0.007 & 0 & 4.2 & 4.72 \\
\hline & $\mathrm{A} 16 \mathrm{~N}$ & $19.8^{\circ} \mathrm{W}, 59.1^{\circ} \mathrm{N}$ & -1.54 & 0.25 & 2.23 & 1.85 & -0.02 & 0.0005 & 3.34 & 10.17 \\
\hline
\end{tabular}

${ }^{a}$ Crossover values are the differences between values for each cruise and the value for the crossover cruise (column 1). Italicized values are from cruises that were not retained in the synthesis.

${ }^{b}$ If more than one station of a cruise was used in a crossover, the mean values are given for the averages and standard deviations. 
used to create the regressions. DIC and TAlk data from greater than $1500 \mathrm{~m}$ were fit with an MLR as a function of common hydrographic parameters. After calculation of the linear regression, it was possible to investigate the residuals for evidence of systematic differences between the various cruises. Details of the procedure can be found in Key $(1999,2000)$. The data quality of the independent variables was checked in the regional MLR technique to minimize potential biases resulting from an artificial offset in one of the independent variables.

The following regressions were solved for the coefficients $\alpha_{x}$ and $\beta_{x}$ :

$$
\begin{gathered}
D I C=\alpha_{1}+\alpha_{2} S+\alpha_{3} \theta+\alpha_{4} A O U+\alpha_{5} N_{3}+\alpha_{6} \mathrm{SiO}_{2} \\
\text { TAlk }=\beta_{1}+\beta_{2} S+\beta_{3} \theta+\beta_{4} \mathrm{NO}_{3}+\beta_{5} \mathrm{SiO}_{2}
\end{gathered}
$$

where

$\alpha$ and $\beta=$ constants,

$S=$ salinity,

$\theta=$ potential temperature, ${ }^{\circ} \mathrm{C}$,

$A O U=$ apparent oxygen utilization, $\mu \mathrm{mol} / \mathrm{kg}$,

$\mathrm{NO}_{3}=$ nitrate, $\mu \mathrm{mol} / \mathrm{kg}$,

$\mathrm{SiO}_{2}=$ silicate, $\mu \mathrm{mol} / \mathrm{kg}$.

The coefficients were determined from regressions of the data from the cruises listed as "control" in Tables 6 and 7. The independent variables used for the fits $\left(\theta, S, A O U, \mathrm{SiO}_{2}\right.$ for TAlk; and $\theta, S$, $A O U, \mathrm{SiO}_{2}, \mathrm{NO}_{3}$ for DIC) are closely related to response variables (DIC and TAlk). Potential temperature, $\theta$, and salinity, $S$, for example, represent physical factors that influence DIC and TAlk, while $A O U$ accounts for the biological effects. However, several different parameters can represent the same process. The choice of parameters used to represent the processes that affect DIC and TAlk were based on previous work in the Pacific (Lamb et al. 2001).

The Atlantic Ocean is divided into three regions: (1) north of $15^{\circ} \mathrm{N},(2)$ between $15^{\circ} \mathrm{N}$ and $15^{\circ} \mathrm{S}$, and (3) south of $15^{\circ} \mathrm{S}$. Water mass characteristics for each of these regions are different, and thus the coefficients of the MLR are different.

For DIC, the cruises used as controls in region 1 (north of $15^{\circ} \mathrm{N}$ ) included A01E, A01W, A02, A05R, A16N, A20, A22, and A24 (see Table 6 for details). The cruises used as "unknown" were $\mathrm{A} 05$ and $\mathrm{A} 01 \mathrm{WR}$. In region 2 (between $15^{\circ} \mathrm{N}$ and $15^{\circ} \mathrm{S}$ ), the cruises used as controls included A08, A13, A14, A15, A16N, and A20. Those used as unknowns were A06, A07, A16S, A22, and A17. In region 3 (south of $15^{\circ} \mathrm{S}$ ) the controls were A10, A13, A14, A15, and A16S. The unknowns were A09, A12, A12B, A12BR, A17, A21, and IO6. The Indian Ocean cruise IO6 along $30^{\circ} \mathrm{E}$ was included in the Atlantic synthesis as a boundary cruise between the Indian and Atlantic oceans. Data from IO6 were consistent with other Indian Ocean data based on similar quality checks (Millero et al. 1998, Sabine et al. 1999). The correlation coefficient, standard error, and coefficients for the best-fit equations obtained from the controls for each region for depths greater than $1500 \mathrm{~m}$ are as follows.

- Region 1 -north of $15^{\circ} \mathrm{N}, \mathrm{N}=3130, R^{2}=0.95$, residual standard error $=3.44 \mu \mathrm{mol} / \mathrm{kg}$

$$
D I C=2519.890-11.741 \mathrm{~S}+1.418 \mathrm{~T}+0.369 \mathrm{AOU}+0.896 \mathrm{NO}_{3}+0.693 \mathrm{SiO}_{2}
$$


- Region 2-between $15^{\circ} \mathrm{N}$ and $15^{\circ} \mathrm{S}, \mathrm{N}=1751, R^{2}=0.93$, residual standard error $=5.72$ $\mu \mathrm{mol} / \mathrm{kg}$

$$
D I C=783.944+38.214 \mathrm{~S}+0.369 \mathrm{~T}+0.033 \mathrm{AOU}+1.375 \mathrm{NO}_{3}+0.974 \mathrm{SiO}_{2}
$$

- Region 3-south of $15^{\circ} \mathrm{S}, \mathrm{N}=1388, R^{2}=0.95$, residual standard error $=4.68 \mu \mathrm{mol} / \mathrm{kg}$

$$
D I C=4546.784-69.213 \mathrm{~S}+5.210 \mathrm{~T}+0.009 \mathrm{AOU}+0.385 \mathrm{NO}_{3}+0.887 \mathrm{SiO}_{2}
$$

Predicted DIC values were computed with these equations and were compared with observed values. The mean difference between observed DIC and the predicted DIC (i.e., observed minus predicted) for each of the cruises is given in Table 6.

For TAlk, the cruises used as controls in region 1 included A05, A05R, A16N, A22, and A24. The unknown cruises were A01E, A01W, A02, and A20. In region 2, the controls were A14, A15, A16N, A16S, and A22. The unknowns were A06, A07, A08, A17, and A20. In region 3, the

Table 6. Results of the multiple-parameter linear regression checks of dissolved

\begin{tabular}{|c|c|c|c|c|c|}
\hline Location & Cruise & Mean & StDev & n & Type \\
\hline \multirow[t]{10}{*}{ North of $15^{\circ} \mathrm{N}$} & A05 & -0.40 & 8.39 & 175 & Unknown (calc) ${ }^{a}$ \\
\hline & A01WR & -0.83 & 3.01 & 145 & Unknown \\
\hline & A01E & -0.78 & 2.98 & 227 & Control \\
\hline & A01W & 0.86 & 3.77 & 355 & Control \\
\hline & A02 & 0.98 & 2.12 & 223 & Control \\
\hline & A05R & 1.73 & 3.55 & 642 & Control \\
\hline & A16N & 1.38 & 3.22 & 307 & Control \\
\hline & A20 & -3.49 & 1.94 & 451 & Control \\
\hline & A22 & -2.24 & 2.92 & 410 & Control \\
\hline & A 24 & 1.66 & 2.54 & 515 & Control \\
\hline \multirow[t]{11}{*}{$15^{\circ} \mathrm{N}$ to $15^{\circ} \mathrm{S}$} & A06 & 14.95 & 12.39 & 550 & Unknown \\
\hline & $\mathrm{A} 07$ & 10.60 & 12.09 & 640 & Unknown \\
\hline & A17 & -3.39 & 3.02 & 662 & Unknown \\
\hline & A16S & -47.91 & 12.94 & 33 & Unknown \\
\hline & A22 & 9.00 & 2.21 & 42 & Unknown \\
\hline & A08 & 0.54 & 5.87 & 652 & Control \\
\hline & A13 & -2.82 & 4.80 & 283 & Control \\
\hline & A14 & 0.31 & 2.40 & 182 & Control \\
\hline & A15 & -2.01 & 3.05 & 229 & Control \\
\hline & A16N & -1.74 & 3.51 & 255 & Control \\
\hline & A20 & -1.00 & 1.74 & 150 & Control \\
\hline \multirow[t]{13}{*}{ South of $15^{\circ} \mathrm{S}$} & A09 & 4.81 & 7.76 & 309 & Unknown \\
\hline & A12 & -7.66 & 6.26 & 164 & Unknown \\
\hline & A12B & -2.75 & 6.82 & 74 & Unknown \\
\hline & A12BR & -4.70 & 6.86 & 40 & Unknown \\
\hline & A17 & -0.63 & 4.30 & 456 & Unknown \\
\hline & A21 & -7.37 & 11.45 & 72 & Unknown \\
\hline & A 23 & -21.11 & 14.46 & 18 & Unknown \\
\hline & I06 & -16.47 & 11.51 & 418 & Unknown \\
\hline & A10 & -0.24 & 4.56 & 468 & Control \\
\hline & A13 & 2.58 & 4.56 & 437 & Control \\
\hline & A14 & 0.14 & 3.58 & 212 & Control \\
\hline & A15 & -4.09 & 2.28 & 233 & Control \\
\hline & A16S & -2.62 & 3.59 & 38 & Control \\
\hline
\end{tabular}
inorganic carbon (observed - predicted)

\footnotetext{
${ }^{a}$ Calculated from $\mathrm{pH}$ and total alkalinity.
} 
controls were A10, A14, A15, and A16S. The unknowns were A09, A12, A21, A23 and A17. The best-fit MLR equations obtained from the control cruises for TAlk are as follows.

- Region 1 -north of $15^{\circ} \mathrm{N}, \mathrm{N}=1759, R^{2}=0.93$, residual standard error $=4.2 \mu \mathrm{mol} / \mathrm{kg}$

$$
\text { TAlk }=-450.510+77.811 \mathrm{~S}-3.706 \mathrm{~T}+2.570 \mathrm{NO}_{3}+0.808 \mathrm{SiO}_{2}
$$

- Region 2 - between $15^{\circ} \mathrm{N}$ and $15^{\circ} \mathrm{S}, \mathrm{N}=737, R^{2}=0.78$, residual standard error $=6.9$ $\mu \mathrm{mol} / \mathrm{kg}$

$$
\text { TAlk }=808.654+43.164 \mathrm{~S}-18.971 \mathrm{~T}+3.765 \mathrm{NO}_{3}+0.408 \mathrm{SiO}_{2}
$$

- $\quad$ Region 3 - south of $15^{\circ} \mathrm{S}, \mathrm{N}=754, R^{2}=0.67$, residual standard error $=8.4 \mu \mathrm{mol} / \mathrm{kg}$

$$
\text { TAlk }=-634.340+84.305 \mathrm{~S}-3.401 \mathrm{~T}+0.588 \mathrm{NO}_{3}+0.560 \mathrm{SiO}_{2}
$$

TAlk values were computed with these equations and were compared with observed values. The mean difference between observed TAlk and the predicted TAlk (i.e., observed minus predicted)

\begin{tabular}{|c|c|c|c|c|c|}
\hline Location & Cruise & Mean & StDev & $\mathrm{n}$ & Type \\
\hline \multirow[t]{10}{*}{ North of $15^{\circ} \mathrm{N}$} & A01E & 69.61 & 20.23 & 39 & Unknown \\
\hline & $\mathrm{A} 01 \mathrm{~W}$ & -13.94 & 20.18 & 337 & Unknown \\
\hline & A01WR & -5.66 & 10.95 & 128 & Unknown \\
\hline & A02 & 3.50 & 5.71 & 225 & Unknown \\
\hline & A20 & -5.86 & 3.76 & 411 & Unknown \\
\hline & A05 & 0.44 & 7.92 & 193 & Control \\
\hline & $A 05 R$ & -0.82 & 4.48 & 366 & Control \\
\hline & $\mathrm{A} 16 \mathrm{~N}$ & 0.48 & 4.00 & 312 & Control \\
\hline & A22 & -0.85 & 2.89 & 371 & Control \\
\hline & A24 & 0.73 & 2.38 & 517 & Control \\
\hline \multirow[t]{10}{*}{$15^{\circ} \mathrm{N}$ to $15^{\circ} \mathrm{S}$} & A06 & 28.85 & 14.58 & 544 & Unknown \\
\hline & A07 & 21.17 & 13.49 & 629 & Unknown \\
\hline & A08 & -2.97 & 7.43 & 639 & Unknown-calc ${ }^{a}$ \\
\hline & A17 & 4.87 & 4.80 & 727 & Unknown \\
\hline & A20 & -2.46 & 5.03 & 147 & Unknown \\
\hline & A14 & 4.97 & 3.63 & 234 & Control \\
\hline & A15 & -3.22 & 4.02 & 223 & Control \\
\hline & $\mathrm{A} 16 \mathrm{~N}$ & -0.90 & 6.41 & 208 & Control \\
\hline & A16S & -7.41 & 15.48 & 35 & Control $^{b}$ \\
\hline & A22 & 26.54 & 2.61 & 37 & Control $^{b}$ \\
\hline \multirow[t]{10}{*}{ South of $15^{\circ} \mathrm{S}$} & A09 & 9.85 & 8.95 & 60 & Unknown \\
\hline & A17 & 6.24 & 4.53 & 477 & Unknown \\
\hline & A12 & -13.05 & 7.67 & 164 & Unknown-calc ${ }^{a}$ \\
\hline & A21 & -12.86 & 7.76 & 4 & Unknown-calc $^{a}$ \\
\hline & $\mathrm{A} 23$ & -8.16 & 21.81 & 36 & Unknown-calc ${ }^{a}$ \\
\hline & IO6 & -11.39 & 10.22 & 398 & Unknown \\
\hline & A10 & -0.99 & 9.80 & 228 & Control \\
\hline & A14 & 6.16 & 5.33 & 255 & Control \\
\hline & A15 & -4.48 & 3.99 & 229 & Control \\
\hline & A16S & -7.57 & 8.24 & 42 & Control \\
\hline
\end{tabular}
for each of the cruises are given in Table 7.

Table 7. Results of the multiple-parameter linear regression checks of total

${ }^{a}$ Calculated from $\mathrm{pH}$ and total alkalinity.

${ }^{b}$ These cruises should have been treated as an unknown. However, because of the small number of samples, it does not affect the coefficients determined in the multiple-parameter linear regression. 


\subsection{The Multiple-Parameter Linear Regression Method for Checking Overlapping Cruises}

Several of the cruise lines were completely or partially reoccupied during the 1990s, and the MLR technique was used to compare the overlapping cruise data as well. This method is preferable to direct comparison because biogeochemical variables often co-vary in a systematic fashion in water masses. Water mass movement between the times of investigation is thus (partially) accounted for in the MLR technique. The following cruises were compared: A05 with A05R, A16N with A16S, A01W with A24, A01W with A01WR, and A12B with A12BR. The suffix "R" stands for repeat occupation. ${ }^{2}$ The coefficients for the MLR were determined by combining data from both cruises in question. Multiple-parameter linear fits of the form

and

$$
D I C=\alpha_{1}+\alpha_{2} S+\alpha_{3} \theta+\alpha_{4} A O U+\alpha_{5} N_{3}+\alpha_{6} S i O_{2},
$$

$$
\text { TAlk }=\beta_{1}+\beta_{2} S+\beta_{3} \theta+\beta_{4} \mathrm{NO}_{3}+\beta_{5} \mathrm{SiO}_{2}
$$

were created for the combined data set, and the average differences between the observed points and calculated values (observed minus predicted from the fit) were determined (Table 8).

The MLR was applied over different depth ranges, depending on number of samples and the density structure. In general, samples at depths greater than $1500 \mathrm{~m}$ were used to avoid biases from variations in the upper water column. For the A16N/A16S comparison between $4^{\circ} \mathrm{N}$ and $4^{\circ} \mathrm{S}$ along $25^{\circ} \mathrm{W}$, the criteria were relaxed to include depths up to $200 \mathrm{~m}$ to get a sufficient number of samples. Because both cruises were run in the summer, seasonal variability should not have unduly affected the values. For the high-northern-latitude A24 and A01 W cruises, only samples deeper than $3000 \mathrm{~m}$ were analyzed because the high-latitude regions experience deep ventilation and the two cruises did not overlap exactly in space. No significant differences were observed for DIC between overlapping cruises. Significant differences were observed for TAlk for A24, A01W, and A01WR, but these differences were generally within one standard deviation. As described below, these results were used as corroborative evidence of systematic offsets between cruises.

\subsection{Other Inorganic Carbon System Parameters}

The primary uses for $\mathrm{pH}$ and $f \mathrm{CO}_{2}$ measurements in this work are to determine the internal consistency of the inorganic carbon measurements when three or four carbon parameters were measured and to calculate TAlk or DIC on the cruises when these state variables were not measured. In these cases, DIC and $\mathrm{pH}\left(\right.$ or $f \mathrm{CO}_{2}$ ) are used to determine TAlk, and TAlk and $\mathrm{pH}$ ( or $f \mathrm{CO}_{2}$ ) are used to calculate DIC. The $f \mathrm{CO}_{2}$ and $\mathrm{pH}$ data on cruises were compared by using the same crossover analyses as DIC and TAlk, but no recommendations are made regarding adjustments because the paucity of $f \mathrm{CO}_{2}$ and $\mathrm{pH}$ data makes it difficult to sufficiently evaluate these parameters.

\subsection{1 pH}

Electrodes or spectrophotometry were used to measure $\mathrm{pH}$. The spectrophotometric $\mathrm{pH}$ measurements have excellent precision, of 0.001 or better (McElligott et al. 1998). Because $\mathrm{pH}$ is

\footnotetext{
${ }^{2}$ Throughout this report the standard WOCE/WHP cruise identifiers were used except for the repeat occupations, which are listed by the WOCE/WHP primary cruise identifier with an "R" attached rather than the official WOCE/WHP repeat cruise designation, "ARXX."
} 


\begin{tabular}{|c|c|c|c|c|c|c|c|c|c|c|c|c|}
\hline \multirow[t]{2}{*}{ Overlap } & \multicolumn{2}{|c|}{ Nominal position } & \multirow{2}{*}{$\begin{array}{l}\text { Cruise name/ } \\
\text { WOCE line }\end{array}$} & \multirow[b]{2}{*}{ Dates of occupation } & \multirow{2}{*}{$\begin{array}{l}\text { Station } \\
\text { range }\end{array}$} & \multirow{2}{*}{$\begin{array}{l}\text { Depth } \\
\text { range }\end{array}$} & \multicolumn{3}{|c|}{ Dissolved inorganic carbon } & \multicolumn{2}{|c|}{ Total alkalinity } & \multirow[b]{2}{*}{$\begin{array}{l}\text { Number of } \\
\text { samples }\end{array}$} \\
\hline & $\begin{array}{l}\text { Longitude } \\
\text { range }\end{array}$ & $\begin{array}{l}\text { Latitude } \\
\text { range }\end{array}$ & & & & & Ave & StDev & $\begin{array}{l}\text { Number of } \\
\text { samples }\end{array}$ & Ave & StDev & \\
\hline \multirow[t]{4}{*}{ A05/A05R } & $23.85^{\circ} \mathrm{W}$ & $24.5^{\circ} \mathrm{N}$ & A5R & 28 Jan to 16 Feb 1998 & 22 & $>1500$ & 0.4 & 3.0 & 534 & 0.0 & 4.4 & 313 \\
\hline & $69.13^{\circ} \mathrm{W}$ & $24.5^{\circ} \mathrm{N}$ & A5R & & 89 & & & & & & & \\
\hline & $23.34^{\circ} \mathrm{W}$ & $24.5^{\circ} \mathrm{N}$ & A5 & 24 July to 11 Aug 1992 & 17 & $>1500$ & -1.6 & 8.1 & 144 & 0.0 & 7.7 & 159 \\
\hline & $69.33^{\circ} \mathrm{W}$ & $24.5^{\circ} \mathrm{N}$ & A5 & & 89 & & & & & & & \\
\hline \multirow[t]{4}{*}{ A16S/A16N } & $25^{\circ} \mathrm{W}$ & $4^{\circ} \mathrm{N}$ & A16S & 16 July to 20 July 1991 & 7 & $>200$ & -1.0 & 6.1 & 99 & -1.0 & 8.9 & 71 \\
\hline & $25^{\circ} \mathrm{W}$ & $4^{\circ} \mathrm{S}$ & A16S & & 12 & & & & & & & \\
\hline & $25^{\circ} \mathrm{W}$ & $4^{\circ} \mathrm{S}$ & $\mathrm{A} 16 \mathrm{~N}$ & 8 July to 10 July 1993 & 4 & $>200$ & 0.2 & 4.1 & 281 & 0.4 & 5.7 & 261 \\
\hline & $25^{\circ} \mathrm{W}$ & $4^{\circ} \mathrm{N}$ & $\mathrm{A} 16 \mathrm{~N}$ & & 14 & & & & & & & \\
\hline \multirow[t]{4}{*}{ A01W/A24 } & $41.96^{\circ} \mathrm{W}$ & $58.84^{\circ} \mathrm{N}$ & A24 & 19 June to 21 June 1997 & 103 & $>3000$ & 0.5 & 1.7 & 167 & 3.6 & 1.9 & 151 \\
\hline & $37.07^{\circ} \mathrm{W}$ & $54.84^{\circ} \mathrm{N}$ & A24 & & 114 & & & & & & & \\
\hline & $41.73^{\circ} \mathrm{W}$ & $58.59^{\circ} \mathrm{N}$ & $\mathrm{A} 01 \mathrm{~W}$ & 17 June to 19 June 1995 & 44 & $>3000$ & -0.5 & 1.5 & 111 & -2.8 & 16.0 & 200 \\
\hline & $37.07^{\circ} \mathrm{W}$ & $55.03^{\circ} \mathrm{N}$ & $\mathrm{A} 01 \mathrm{~W}$ & & 55 & & & & & & & \\
\hline \multirow[t]{4}{*}{ A01W/A01WR } & $53.98^{\circ}$ & $55.26^{\circ} \mathrm{N}$ & $\mathrm{A} 01 \mathrm{~W}$ & 13 June to 26 June 1995 & 11 & $>1500$ & 1.6 & 2.1 & 406 & -7.1 & 13.7 & 247 \\
\hline & $48.28^{\circ} \mathrm{W}$ & $58.59^{\circ} \mathrm{N}$ & $\mathrm{A} 01 \mathrm{~W}$ & & 43 & & & & & & & \\
\hline & $53.82^{\circ} \mathrm{W}$ & $55.41^{\circ} \mathrm{S}$ & A01WR & 28 June to 3 July 1998 & 48 & $>1500$ & -1.7 & 2.8 & 151 & 5.2 & 13.1 & 271 \\
\hline & $49.16^{\circ} \mathrm{W}$ & $59.74^{\circ} \mathrm{S}$ & A01WR & & 97 & & & & & & & \\
\hline \multirow[t]{4}{*}{ A12B/A12BR } & $0^{\circ} \mathrm{W}$ & $55^{\circ} \mathrm{S}$ & A12B & 8 June to 27 July 1992 & 576 & $>1500$ & 0.0 & 2.5 & 195 & & & \\
\hline & $48.65^{\circ} \mathrm{W}$ & $60.17^{\circ} \mathrm{S}$ & A12B & & 641 & & & & & & & \\
\hline & $3.06^{\circ} \mathrm{E}$ & $58.60^{\circ} \mathrm{S}$ & A12BR & 3April to 7 May 1996 & 29 & $>1500$ & 0.0 & 2.5 & 452 & & & \\
\hline & $50.84^{\circ} \mathrm{W}$ & $63.73^{\circ} \mathrm{S}$ & $\mathrm{A} 12 \mathrm{BR}$ & & 99 & & & & & & & \\
\hline
\end{tabular}


very sensitive to changes in TAlk and DIC, it can be used to discern minute changes in them. For example, for North Atlantic deep water with DIC $=2192 \mu \mathrm{mol} / \mathrm{kg}$, TAlk $=2349 \mu \mathrm{mol} / \mathrm{kg}$, and pHsw $\left(25^{\circ} \mathrm{C}\right)=7.7417$, a $1-\mu \mathrm{mol} / \mathrm{kg}$ change in DIC will result in a 0.0023 change in $\mathrm{pH}$.

However, the accuracy of the measurements is not well quantified and is currently under debate (DelValls and Dickson 1998, Millero et al. submitted). CRMs were used to normalize $\mathrm{pH}$ values on cruises A13, A14, and A17 by calculating pH from the certified DIC and TAlk values and from the dissociation constants recommended by Mehrbach et al. (1973). The measured $\mathrm{pH}$ values were then normalized to the mean calculated CRM value for each cruise (Ríos and Perez 1999)

Eleven of the 24 cruises had $\mathrm{pH}$ measurements. Different analysis techniques were used, and the $\mathrm{pH}$ values were recorded on different reference scales. Metadata provided with the $\mathrm{pH}$ measurements often were not sufficient to fully comprehend methods and corrections. A summary of the metadata is provided in Table 9. Much of the $\mathrm{pH}$ data were reported at $25^{\circ} \mathrm{C}$ on the seawater scale $\left[\mathrm{pHsw}\left(25^{\circ} \mathrm{C}\right)\right]$. The data from A16N, A17C, and A14 that were not reported at $25^{\circ} \mathrm{C}$ and on the SW scale were corrected to $\mathrm{pHsw}\left(25^{\circ} \mathrm{C}\right)$ in order to perform the crossover analyses. The conversion was done by using the program of Lewis, Wallace, and Allison (1998) and by applying the carbonate dissociation constants of Mehrbach et al. (1973) as refitted by Dickson and Millero (1987). Because the temperature dependence of $\mathrm{pH}$ is not well known, these adjustments (and therefore the crossover comparison) should be viewed with caution.

Table 9. Summary of metadata for cruises with $\mathrm{pH}$ measurements

\begin{tabular}{|c|c|c|c|c|c|}
\hline Cruise & Method & Temp. $\left({ }^{\circ} \mathrm{C}\right)$ & Calibration $^{a}$ & Principal investigator & Remarks $^{b}$ \\
\hline $\mathrm{A} 05^{c}$ & Potentiometric & 25 & Yes & Ríos & $\mathrm{OK}$ \\
\hline A5R & Spectroscopic & 25 & Yes & Millero & $\mathrm{OK}$ \\
\hline A06 & Potentiometric & $d$ & $d$ & $d$ & No \\
\hline A07 & Potentiometric & $d$ & $d$ & $d$ & No \\
\hline A14 & Potentiometric & $15^{e}$ & Yes & Ríos & $\mathrm{No}^{e}$ \\
\hline $\mathrm{A} 16 \mathrm{~N}$ & Spectroscopic & 20 & Yes & Millero & OK \\
\hline A16S & Potentiometric & 25 & No & Millero & No \\
\hline $\mathrm{A} 17 \mathrm{C}^{e}$ & Potentiometric & $15^{e}$ & $\mathrm{No}^{e}$ & Ríos & $\mathrm{No}^{e}$ \\
\hline $\mathrm{A} 20^{f}$ & Potentiometric & 25 & Yes & Millero/Sabine & No \\
\hline $\mathrm{A} 22^{f}$ & Potentiometric & 25 & Yes & Millero Sabine & No \\
\hline $\mathrm{A} 24^{f}$ & Potentiometric & 25 & Yes & Millero/Sabine & No \\
\hline $\begin{array}{r}{ }^{a} \text { Yes } \\
\text { shore. N } \\
{ }^{b} \text { Recc } \\
\text { and intel } \\
{ }^{c} \text { Mea } \\
\text { scale by } \\
{ }^{d} \text { Unk } \\
{ }^{e} \text { Rep } \\
{ }^{f} \text { Not }\end{array}$ & $\begin{array}{l}\text { I values are norr } \\
\mathrm{pH} \text { values were } \\
\text { lendation of Kita } \\
\text { consistency. OK } \\
\mathrm{d} \text { on the Nationa } \\
\text { cipal investigato } \\
\mathrm{n} \text {. } \\
\text { on the NBS sca } \\
\text { ned reliable (Mil }\end{array}$ & $\begin{array}{l}\text { zed by using c } \\
\text { eferenced to } \\
\text { ee and Frank } \\
\text { commended, } \\
\text { reau of Stand } \\
\text { Ríos). }\end{array}$ & $\begin{array}{l}\text { rtified referenc } \\
\text { RMs. } \\
\text { Millero whethe } \\
\text { Jo = not recom } \\
\text { ds (NBS) scal }\end{array}$ & $\begin{array}{l}\text { materials (CRMs) calibr } \\
\mathrm{H} \text { is reliable for crossov } \\
\text { lended. } \\
\text { at } 15^{\circ} \mathrm{C} \text { but reported at } 25\end{array}$ & $\begin{array}{l}\text { ed on } \\
\text { analysis } \\
\text { C seawater }\end{array}$ \\
\hline
\end{tabular}

A16N data were provided on the seawater scale at $20^{\circ} \mathrm{C}$. The correction to $25^{\circ} \mathrm{C}$ was performed by using the measured DIC and pHsw $\left(20^{\circ} \mathrm{C}\right)$ and the Lewis, Wallace, and Allison (1998) program. The A14 and A17 data were provided on the National Bureau of Standards (NBS) scale at $15^{\circ} \mathrm{C}$. Correction to $25^{\circ} \mathrm{C}$ on the seawater scale was done by first calculating $f \mathrm{CO}_{2}$ from DIC and $\mathrm{pHnbs}\left(15^{\circ} \mathrm{C}\right)$, and then by using the DIC and calculated $f \mathrm{CO}_{2}$ to determine $\mathrm{pHsw}\left(25^{\circ} \mathrm{C}\right)$. Both the original reported $\mathrm{pH}$ data and the converted data are presented in the working synthesis data files. 


\subsubsection{Fugacity of $\mathrm{CO}_{2}$}

The fugacity of $\mathrm{CO}_{2}$ was measured throughout the water column on seven cruises. Like $\mathrm{pH}$, the measurements were performed at a fixed temperature. Agreement between cruises was good (see Table 4), considering that there were no liquid reference materials and that gas standards used by different groups were not intercalibrated. The precision of the measurements depends on the methodology, but in general it was better than $2 \mu \mathrm{atm}$ for surface waters $(<500 \mu \mathrm{atm})$ and within $1 \%$ of the measured value for deep water. The $f \mathrm{CO}_{2}\left(20^{\circ} \mathrm{C}\right)$ is very sensitive to changes in TAlk and DIC, particularly in deep water. For example, for North Atlantic deep water with $\mathrm{DIC}=2192 \mu \mathrm{mol} / \mathrm{kg}$, TAlk $=2349 \mu \mathrm{mol} / \mathrm{kg}$, and $f \mathrm{CO}_{2}\left(20^{\circ} \mathrm{C}\right)=757 \mu \mathrm{atm}$, a $1 \mu \mathrm{mol} / \mathrm{kg}$ change in DIC will result in a 5- $\mu$ atm change in $f \mathrm{CO}_{2}\left(20^{\circ} \mathrm{C}\right)$. Thus a commonly quoted DIC precision of $2 \mu \mathrm{mol} / \mathrm{kg}$ corresponds to a $10 \mu \mathrm{atm}$ uncertainty in $f \mathrm{CO}_{2}\left(20^{\circ} \mathrm{C}\right)$ for deep water. The only crossover that exhibited significant differences was that of A16S and A8 (see Table 5). Based on the internal consistency analyses (see Sect. 3.5), the difference in measured TAlk and calculated TAlk [from DIC and $f \mathrm{CO}_{2}\left(20^{\circ} \mathrm{C}\right)$ ] for A16S of $-3.6 \mu \mathrm{mol} / \mathrm{kg}$ suggests that the A16S deep-water $f \mathrm{CO}_{2}\left(20^{\circ} \mathrm{C}\right)$ measurements are low by 10 to $15 \mu \mathrm{atm}$.

\subsection{Internal Consistency Checks}

For cruises in which more than two inorganic carbon system parameters were measured, it is possible to assess the agreement of the inorganic carbon data by an internal consistency check. With knowledge of the apparent carbonate dissociation constants and two carbon system parameters, the other two can be calculated. Although there remains controversy about the accuracy of the carbonate-dissociation constants, there is increasing evidence that those of Merhbach et al. (1973) as refit by Dickson and Millero (1987) yield consistent results (Lee et al. 2000, Millero et al. submitted). Internal consistency checks were performed for cruises where three or four parameters were measured. The results are presented in Table 10.

Table 10. Summary of internal consistency on Atlantic $\mathrm{CO}_{2}$ data sets

\begin{tabular}{|c|c|c|c|c|c|c|c|c|}
\hline \multirow{2}{*}{ Cruise } & \multicolumn{2}{|c|}{ pH + TAlk $\Delta$ DIC $^{a, b}$} & \multicolumn{2}{|c|}{ pH + DIC $\Delta$ TAlk $^{a, b}$} & \multicolumn{2}{|c|}{$f \mathrm{CO}_{2}+$ TAlk $\Delta \mathrm{DIC}^{a, b}$} & \multicolumn{2}{|c|}{$f \mathrm{CO}_{2}+$ DIC $\Delta \mathrm{TAlk}^{a, b}$} \\
\hline & Mean & StDev & Mean & StDev & Mean & StDev & Mean & StDev \\
\hline$A 06^{c}$ & 87.5 & 37.1 & -87.5 & 40.4 & -92.9 & 7.9 & 92.9 & 9.5 \\
\hline$A 07^{c}$ & 89.4 & 34.5 & -89.4 & 37.5 & -83.4 & 10.5 & 83.4 & 12.6 \\
\hline A14 & -4.6 & 3.8 & 4.8 & 4.0 & & & & \\
\hline A 17 & -7.2 & 4.3 & 7.5 & 4.5 & & & & \\
\hline A20 & 3.3 & 2.9 & -3.6 & 3.1 & 0.3 & 3.0 & -0.4 & 3.4 \\
\hline A22 & 0.7 & 2.9 & -0.9 & 3.1 & -2.3 & 2.4 & 2.5 & 2.8 \\
\hline A24 & -8.6 & 3.8 & 8.9 & 4.0 & -2.9 & 3.9 & 3.2 & 4.5 \\
\hline $\mathrm{A} 16 \mathrm{~N}$ & -3.7 & 3.6 & 3.8 & 4.2 & -0.9 & 4.5 & 1.0 & 5.1 \\
\hline A16S & & & & & 3.3 & 11.6 & -3.7 & 13.5 \\
\hline $\mathrm{A} 05 \mathrm{R}$ & -1.6 & 4.2 & 1.6 & 4.4 & 0.4 & 6.4 & -0.5 & 7.4 \\
\hline
\end{tabular}

Of the cruises listed in Table 10, A06 and A07 are not recommended for use in the synthesis because of inconsistent data and because of the absence of appropriate metadata. A17 and A24 show significant differences in measured and calculated TAlk and DIC. For A24 this appears to be an issue with the $\mathrm{pH}$ measurements because the calculation with $f \mathrm{CO}_{2}$ shows reasonable agreement. For A17, Ríos and Perez (1999) show better agreement, having used the original Mehrbach (1973) constants. Because the crossover differences in DIC and TAlk for A17 with 
other cruises are smaller than the internal consistency offset, we attribute this to issues with the applied internal consistency method. When the constants used in our analysis are applied, the difference is consistent over the entire DIC range (Fig. 6) but with a trend with latitude. The pH data for A20, A22, and A24 were measured by potentiometry and, according the responsible investigator (Millero), do not have the accuracy for a robust crossover analysis. 


\section{RECOMMENDATIONS}

The data included in the Atlantic synthesis data set come from diverse sources, and the intercomparisons are complicated by the dynamic nature of the Atlantic Ocean; shifts in bottomwater characteristics have been documented. Therefore, we are being conservative and only recommend adjustments in the synthesis data set when there are clear biases of greater than $4 \mu \mathrm{mol} / \mathrm{kg}$ for DIC and $6 \mu \mathrm{mol} / \mathrm{kg}$ for TAlk. The recommendations are solely for the purpose of this analysis, to produce an internally consistent basin-wide data set of DIC and TAlk that can be used to quantify large-scale characteristics. Data sets that were deemed of insufficient quality for this analysis can have significant intrinsic merits for other applications.

Overall, the data appear to be of high quality, and only a few cruises showed consistent biases for each method. Variability within profiles and between stations often was of the same magnitude as the cruise-to-cruise differences (see Table 4). If adjustments had to be applied, the assessments were somewhat subjective because the statistical evidence of the different methods of comparison had to be weighed in an arbitrary manner. Our approach, as outlined in Sects. 4.1 and 4.2, consisted of first looking at the crossover results (see Tables 4 and 5) for offsets between cruises. From this comparison it was determined whether an offset appeared consistent for a particular cruise at all crossovers with other cruises. Table 5, which has the crossovers ordered per cruise, is particularly useful for this check. DIC anomalies of greater than $4 \mu \mathrm{mol} / \mathrm{kg}$ and TAlk anomalies greater than $6 \mu \mathrm{mol} / \mathrm{kg}$ prompted closer scrutiny. If cruises showed a consistent bias, it was determined whether a similar bias was apparent in the regional MLR, internal consistency, and overlapping cruise regressions. Cruise-by-cruise narratives for crossovers with offsets of DIC greater than $4 \mu \mathrm{mol} / \mathrm{kg}$ (Sect. 4.1) and TAlk greater than $6 \mu \mathrm{mol} / \mathrm{kg}$ (Sect. 4.2) provide a rationale for the proposed adjustments.

In cases of overlapping cruises when only one of the cruises is used, the repeat cruise is recommended. Thus A05R, A01WR, A12BR, and A16N in the equatorial overlap section with A16S are suggested. The repeat cruises are also often closer in time to the other cruises in the synthesis, thereby decreasing the possibility of a temporal bias. However, these overlapping cruises are invaluable for many applications, and all of the individual cruises are retained in the data holdings. Also, the cruise tracks of overlapping cruises sometimes diverge for part of the tracks, and these segments should be included in basinwide analyses.

\subsection{Narrative of DIC Adjustments}

In consideration of all the analyses described in this report, we believe that cruises with consistent offsets in DIC of greater than $4 \mu \mathrm{mol} / \mathrm{kg}$ should be considered for adjustments. The cruises with offsets of this magnitude are discussed in the following subsections.

A06 and A07. The 11 crossovers showed high variability and often large differences along with large standard deviations, suggesting significant variability over the density range investigated. The MLR indicated that these cruises had biases of 11 to $15 \mu \mathrm{mol} / \mathrm{kg}$ with large standard deviations compared with other cruises in this region. These results suggest significant station-tostation differences and possible variability with depth. Therefore, these cruises are not recommended for use.

A08. A08 had crossovers with five other cruises. It was $8 \mu \mathrm{mol} / \mathrm{kg}$ low compared with A17, but the other crossings were not more than $3 \mu \mathrm{mol} / \mathrm{kg}$ lower than other cruises. The MLR showed the cruise to be in line with other cruises in the tropical region. No adjustment is recommended. 
A09. A09 had crossovers with five other cruises. These crossovers showed that A09 had lower values than A16S $(-5 \mu \mathrm{mol} / \mathrm{kg})$ but higher values than A15 $(+8 \mu \mathrm{mol} / \mathrm{kg})$. It was almost $5 \mu \mathrm{mol} / \mathrm{kg}$ high with respect to the regional MLR but had a standard deviation of $8 \mu \mathrm{mol} / \mathrm{kg}$. An adjustment of $-4 \mu \mathrm{mol} / \mathrm{kg}$ would bring the values in line with most of the other transects, but this is at the borderline of suggested adjustments. Given the variability and inconsistency of the different comparisons, no adjustments are recommended.

A10. A10 had crossovers with six other cruises. A10 was $4 \mu \mathrm{mol} / \mathrm{kg}$ higher than A15 but was slightly low relative to the other cruises. It did not appear anomalous in the MLR; therefore, no adjustment is recommended.

A12B. A12B had crossovers with three other cruises. It was $7 \mu \mathrm{mol} / \mathrm{kg}$ high relative to A13 but showed no offset in multiple crossovers with A12 and A12BR. A12B also compared favorably with the MLR. Therefore, no adjustment is recommended.

A13. A13 had four crossovers with other cruises. It was low by $7 \mu \mathrm{mol} / \mathrm{kg}$ relative to A12B but compared favorably in crossovers with three other cruises and in the MLR. It is our assessment that the stations associated with the A13-A12B crossover must be slightly anomalous relative to the rest of the data from these cruises. No adjustment is recommended for A13.

A14. A14 had four crossovers with other cruises. It was $5 \mu \mathrm{mol} / \mathrm{kg}$ high with respect to A10 but compares favorably with A08 and A09 as well as in the MLR. Therefore, no adjustment is recommended.

A15. A15 had six crossovers with other cruises. It was $8 \mu \mathrm{mol} / \mathrm{kg}$ low compared with A09 and was consistently low compared with other cruises except crossover A08, which showed a large standard deviation. The regional MLR suggested that adding $4 \mu \mathrm{mol} / \mathrm{kg}$ would put the values in line with other cruises. This is a borderline case, but no adjustment is recommended.

A16S. A16S had five crossovers with other cruises. A16S was $5 \mu \mathrm{mol} / \mathrm{kg}$ higher than A09 but was consistent with crossovers from four other cruises. A16S was $48 \mu \mathrm{mol} / \mathrm{kg}$ low in the tropical Atlantic MLR, but only 33 samples were included in this analysis. The A16S MLR analysis for the South Atlantic was within $3 \mu \mathrm{mol} / \mathrm{kg}$. The internal consistency and overlap with A16N showed good agreement; thus no adjustment is recommended.

A16N. A16N had seven crossovers with other cruises. It was $6 \mu \mathrm{mol} / \mathrm{kg}$ lower than A05 but with a large standard deviation. The six other crossovers looked very good, as did the overlap MLR and regional MLR. No adjustments are recommended.

A17. A17 had seven crossovers with other cruises. A17 was $9 \mu \mathrm{mol} / \mathrm{kg}$ higher than A08 but was in good agreement with three other crossovers. The MLR showed good agreement in the southern region and a -3 offset in the tropical region. Visual inspection of the crossover plots did not show systematic trends. The internal consistency comparison suggested that either $\mathrm{pH}$, DIC, or TAlk had a bias (Fig. 6). We suspect that the calculation involving $\mathrm{pH}$ is the culprit. The cruise covered a large region and traversed a series of boundary currents that could contribute to the differences. No adjustments are proposed. 


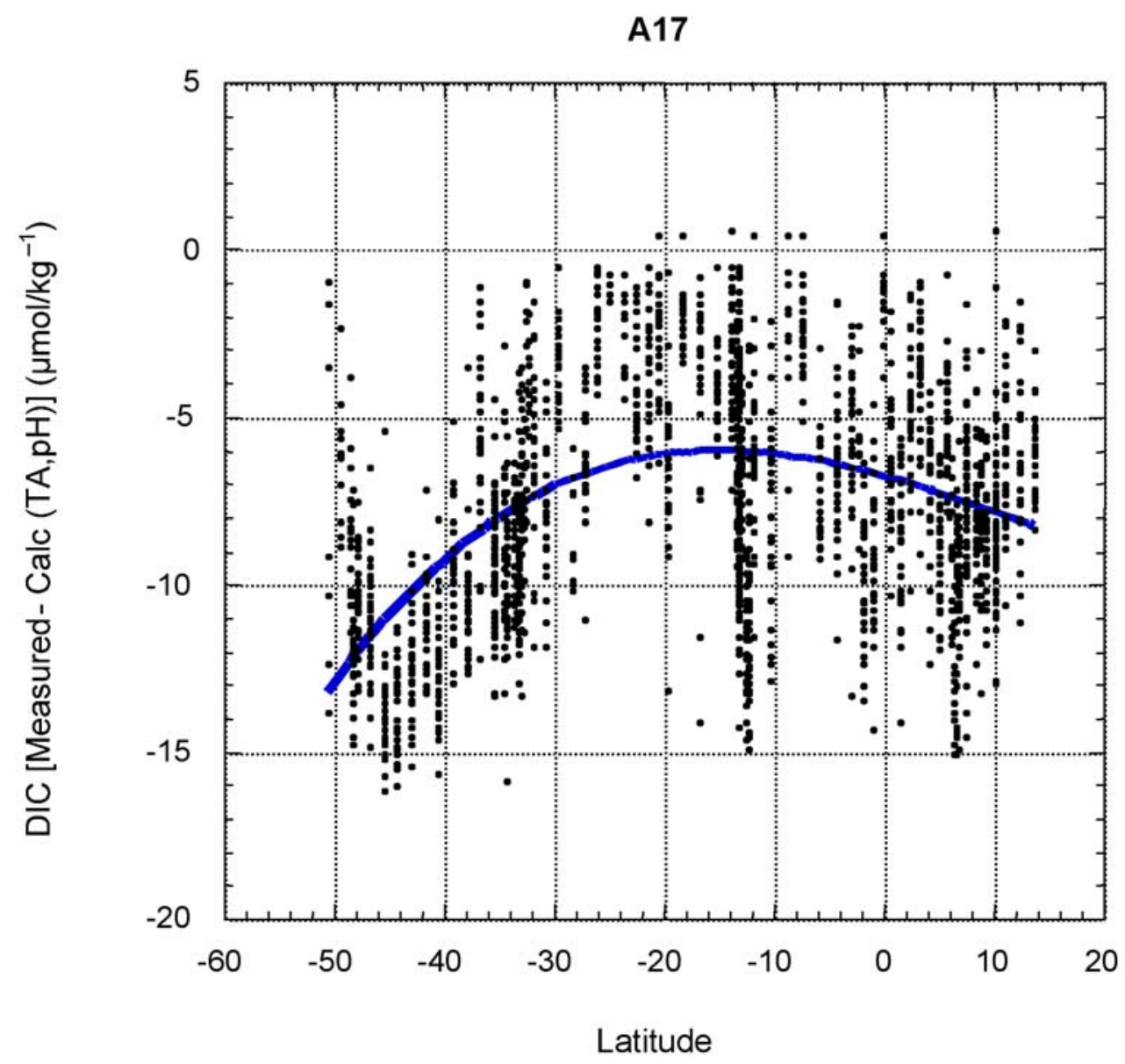

Fig. 6. Measured - calculated (from total alkalinity and $\mathrm{pH}$ ) dissolved inorganic carbon vs latitude for A17. This trend and offset appears to be an artifact of the dissociation constants used in the calculations. This trend was not observed by Ríos and Perez, who used slightly different dissociation constants. (Ríos, A. F., and F. F. Perez. 1999. Improvements in potentiometric determinations of the $\mathrm{CO}_{2}$ oceanic system using substandards and $\mathrm{CO}_{2}$ reference materials. Ciencias Marinas 25: 31-49.)

A20. A20 had three crossovers. It was $4 \mu \mathrm{mol} / \mathrm{kg}$ lower than A05R and 2 to $3 \mu \mathrm{mol} / \mathrm{kg}$ lower than the other overlaps. In the regional MLR it was $3 \mu \mathrm{mol} / \mathrm{kg}$ lower, but the internal consistency with $f \mathrm{CO}_{2}$ was excellent. Applying an adjustment of 2 to $3 \mu \mathrm{mol} / \mathrm{kg}$ would improve the consistency among cruises, but this adjustment is smaller than the overall consistency criteria. No adjustment is recommended.

A22. This cruise was 2 to $3 \mu \mathrm{mol} / \mathrm{kg}$ low based on two crossovers and the internal consistency check with $f \mathrm{CO}_{2}$. The northern MLR also suggested that the A22 DIC values were low by $2 \mu \mathrm{mol} / \mathrm{kg}$, but the tropical MLR suggests that the values are high. Applying an adjustment of 2 to $3 \mu \mathrm{mol} / \mathrm{kg}$ would generally improve the consistency among cruises but this is beyond the overall consistency criteria. No adjustment is recommended.

A23. A23 had three crossovers. There were significant problems with the coulometer (Robertson and Watson, personal communication), and the offsets were not consistent for this cruise. The high-latitude crossover with A12BR at $67^{\circ} \mathrm{S}$ showed a very consistent offset of $-30 \mu \mathrm{mol} / \mathrm{kg}$ 
throughout the water column. However, the crossover with A17 at $29^{\circ} \mathrm{S}$ showed that an offset increased with density, ranging from 0 to $-10 \mu \mathrm{mol} / \mathrm{kg}$. The DIC data for A23 is not recommended for use in the synthesis product.

\subsection{Narrative of TAlk Adjustments}

Alkalinity data showed greater differences than DIC data showed between cruises. Crossovers where deviations were greater than $6 \mu \mathrm{mol} / \mathrm{kg}$ were checked in greater detail. Although adjustments of less then $6 \mu \mathrm{mol} / \mathrm{kg}$ are discussed in the following narrative, we chose not to apply these adjustments, given the uncertainty of the overall data set and the reliability of the assessments at that level of accuracy. That is, for highly precise data sets it is possible to recommend adjustments of less than $6 \mu \mathrm{mol} / \mathrm{kg}$, but the uncertainty for imprecise data is such that adjustment cannot be recommended with confidence.

A01E. There was only one crossover available for evaluation of the A01E alkalinity data. The crossover showed values that were $59 \mu \mathrm{mol} / \mathrm{kg}$ greater than $\mathrm{A} 16 \mathrm{~N}$ with a standard deviation of 17. Such a large offset along with large deviation make the data highly questionable for our purposes. Therefore, it is recommended that the TAlk for cruise A01E not be used.

A01W. For A01W, there were three crossovers for TAlk. Cruise A01W showed values that were systematically low by 4 to $16 \mu \mathrm{mol} / \mathrm{kg}$. The regional analysis showed an offset of $14 \mu \mathrm{mol} / \mathrm{kg}$ in the same direction, albeit with a large standard deviation. Therefore, we recommend an upward correction of $14 \mu \mathrm{mol} / \mathrm{kg}$ for the A01W TAlk values. The TAlk data for this cruise are very noisy, with apparent random scatter of $\pm 20 \mu \mathrm{mol} / \mathrm{kg}$.

A01WR. A01WR had one crossover for TAlk and a significant section of overlap with A01W. The crossover showed a difference of $26 \pm 4 \mu \mathrm{mol} / \mathrm{kg}$ with $\mathrm{A} 01 \mathrm{~W}$. The crossover occurs in a water depth of $300 \mathrm{~m}$, however. The comparison of overlapping cruise tracks between A01W and A01WR using the MLR technique shows a difference of $12 \mu \mathrm{mol} / \mathrm{kg}$. This difference is in accord with the proposed adjustment of A01W of $14 \mu \mathrm{mol} / \mathrm{kg}$ and suggests that A01WR TAlk data do not need to be adjusted. The regional MLR showed an offset of $-5.6 \mu \mathrm{mol} / \mathrm{kg}$. Inspection of the data showed significant scatter with depth and changes from station to station of 10-20 $\mu \mathrm{mol} / \mathrm{kg}$. No adjustment is recommended for A01WR, but it must be recognized that the TAlk data for both A01W and A01WR are of dubious quality.

A02. A02 had four crossovers for TAlk. A02 showed a positive anomaly of $16 \mu \mathrm{mol} / \mathrm{kg}$ with A $01 \mathrm{~W}$, which was reduced to $2 \mu \mathrm{mol} / \mathrm{kg}$ after the proposed adjustment to A01W. A positive anomaly of $11 \mu \mathrm{mol} / \mathrm{kg}$ was also observed with the A20 crossover. However, two A24 crossovers showed an offset of 3 to $4 \mu \mathrm{mol} / \mathrm{kg}$, and the MLR indicated good agreement. Given the inconsistent results, no adjustment is recommended.

A06 and A07. Based on nine crossovers, the offsets and scatter are such that we do not recommend including the data from A06 or A07 in the synthesis product.

A08. The two crossovers suggested that the values for A08 were 4 to $12 \mu \mathrm{mol} / \mathrm{kg}$ low. The regional MLR was $3 \mu \mathrm{mol} / \mathrm{kg}$ low, but we do not feel that there was sufficient evidence to suggest an adjustment.

A09. A single crossover with A17 suggested that the values are $7 \mu \mathrm{mol} / \mathrm{kg}$ high. The regional regression implied a $10-\mu \mathrm{mol} / \mathrm{kg}$ bias in the same direction. A downward correction of $7 \mu \mathrm{mol} / \mathrm{kg}$ is proposed for A09 TAlk. 
A10. There were three crossovers with TAlk for A10. A10 showed a large negative bias with respect to A17, but crossovers with A16S and A15 did not indicate a significant offset. The MLR did not suggest an offset either, so no adjustment is recommended.

A14. There were three crossovers of A14 with other cruises where TAlk was measured. It showed a $12-\mu \mathrm{mol} / \mathrm{kg}$ high offset with A08 but was only $3 \mu \mathrm{mol} / \mathrm{kg}$ high relative to A09. Both the tropical and southern MLR analyses suggested that values were high by about 5 to $6 \mu \mathrm{mol} / \mathrm{kg}$. The internal consistency also suggested that the TAlk could be high by $5 \mu \mathrm{mol} / \mathrm{kg}$. An adjustment of $5 \mu \mathrm{mol} / \mathrm{kg}$ would bring values in better agreement with all analyses, but because this adjustment was less than the $6-\mu \mathrm{mol} / \mathrm{kg}$ criterion, no adjustment was proposed for this synthesis.

A15. There were four crossovers for A15. A15 showed both 8- $\mu \mathrm{mol} / \mathrm{kg}$ high values (with respect to A16S) and $15-\mu \mathrm{mol} / \mathrm{kg}$ low crossover values (with respect to A17), but both had large standard deviations. The regional MLR showed that the TAlk on the cruises was low by about 3 to $4 \mu \mathrm{mol} / \mathrm{kg}$. Given the inconsistency of the results, no adjustment is recommended.

A16S. A16S had three crossovers. It showed an $8-\mu \mathrm{mol} / \mathrm{kg}$ low bias with A15 and a low bias of similar magnitude with the regional MLR in both the tropical and southern regions (albeit with only 35 data points). The internal consistency showed a low bias in TAlk as well, assuming that DIC and $f \mathrm{CO}_{2}$ are accurate. A $4-\mu \mathrm{mol} / \mathrm{kg}$ increase would put the values in better agreement with the other cruises, but because this is less than the minimum adjustment criteria, no adjustment is recommended.

A17. There were six crossovers for A17. A17 showed both significantly high deviations ( $25 \mu \mathrm{mol} / \mathrm{kg}$ with respect to A10 and $15 \mu \mathrm{mol} / \mathrm{kg}$ compared to A15) and low deviations $(-7 \mu \mathrm{mol} / \mathrm{kg}$ with respect to A09) in the crossover analyses. The regional MLR suggested that the TAlk data are 5 to $6 \mu \mathrm{mol} / \mathrm{kg}$ high compared with data from other cruises in the tropical and southern regions. The internal consistency suggested that the TAlk was high by $8 \mu \mathrm{mol} / \mathrm{kg}$. A decrease in TAlk of $6 \mu \mathrm{mol} / \mathrm{kg}$ for A17 TAlk would bring the values in better agreement. Because a decrease was suggested for A09 as well, the bias between these cruises remains of the same magnitude. However, this offset of $6 \mu \mathrm{mol} / \mathrm{kg}$ is right at the recommended cutoff, and no adjustment is recommended.

A20. There were three crossovers of A 20 with other cruises. The alkalinities for this cruise were measured with very high precision but showed systematic offsets in every procedure, except for the assessment of internal consistency conducted by $f \mathrm{CO}_{2}$ and DIC. The TAlk values were low by 3 to $11 \mu \mathrm{mol} / \mathrm{kg}$. The $11-\mu \mathrm{mol} / \mathrm{kg}$ offset was observed with A02, whose TAlk was consistently higher than those of other cruises. A correction of $4 \mu \mathrm{mol} / \mathrm{kg}$ would bring values in line, but no adjustments are proposed.

A24. A24 had six crossovers. A24 showed an offset with A01W but showed good agreement in the MLR analysis. If the suggested correction were applied to A01W, the crossover analysis would fall in line with A24. The assessment of internal consistency conducted by using TAlk, $\mathrm{DIC}$, and $\mathrm{pH}$ showed an offset with $\mathrm{pH}$; however, the $\mathrm{pH}$ data on this cruise were not of highest quality because they were measured by electrode. No adjustment to A24 TAlk data is proposed. 


\subsection{Omitted Cruises}

Based on comprehensive comparisons, the DIC data for cruises A06, A07, and A23 are not included in the combined DIC data set. The following cruises are not included for TAlk: A06, $\mathrm{A} 07$, and A01E. The data from these cruises showed large offsets, large differences for different crossovers (see Table 4), and large scatter, limiting their use in this analysis. Omitting these data significantly decreases data coverage in the equatorial Atlantic.

There were several reoccupations of cruise lines during the decade. For interpretations where only a single cruise along the transect is needed, the repeat occupations later in time are recommended for use. These later cruises are believed to be of higher quality and may contain more parameters. They are also often closer in time to the other cruises. The recommended cruises are A05R (instead of A05), A01WR (instead of A01W), and A12BR (instead of A12B). In the case of $\mathrm{A} 12 \mathrm{~B}$ and $\mathrm{A} 12 \mathrm{BR}$, different cruise tracks were occupied, and there may be merit in retaining both, particularly because the data coverage is so sparse at high southern latitude.

\subsection{Adjustments for the Repeat Lines}

The following adjustments are proposed for parameters measured on the repeat lines.

\subsubsection{Dissolved Inorganic Carbon}

No adjustments are proposed for DIC. Although differences between crossovers were often greater than the stated precision of the measurements $(\approx 2 \mu \mathrm{mol} / \mathrm{kg})$, the differences were not consistent at the $4-\mu \mathrm{mol} / \mathrm{kg}$ level between different crossovers along a line, and/or the standard deviation of the differences were sufficiently large that the differences did not have a strong statistical significance.

\subsubsection{Total Alkalinity}

Crossover analyses and MLR analyses showed consistent offsets for two cruises (A01W and A09). We recommend adding $14 \mu \mathrm{mol} / \mathrm{kg}$ to all TAlk values in A01W and subtracting $7 \mu \mathrm{mol} / \mathrm{kg}$ for all TAlk data on A09. In the combined data set, A01WR was used instead of A01W because the cruise data are compatible with other data in the region and do not require any adjustments. 


\section{SUMMARY}

The comprehensive analysis of the quality of the carbon data of the twenty-three cruises shows general good agreement and high quality. This is testament to the care that was taken in gathering and reducing the data. Extensive use of CRMs facilitated consistency of the DIC and TAlk data sets. Internal consistency calculations for cruises on which three or more carbon system parameters were measured suggest that the $\mathrm{pH}$ and, in particular, $f \mathrm{CO}_{2}$ measurements on the cruises were consistent and of high quality as well. Based on the extensive analyses, we suggest that the DIC and TAlk of two cruises (A06 and A07) not be considered as appropriate for this synthesis. In addition, the TAlk values of A1E are significantly different from neighboring cruises and are not recommended for use, either. A23 has inconsistent DIC data, so these data are also not included in this synthesis. Of the lines that have repeat occupations, we recommend that the later (repeat) cruises be used as the primary data set. This is because the data are more consistent with the other data, in part, because of improved analysis techniques and because they often are closer in time to the other cruises, thus minimizing the effects of anthropogenic and natural variability. No specific adjustments in DIC are recommended. Although crossover analyses often show systematic differences in DIC greater than the assumed precision of $2 \mu \mathrm{mol} / \mathrm{kg}$, the differences either are not systematic for each crossover or do not show up in the regional multilinear analysis. TAlk values show greater inconsistency for some cruises, and adjustments of $+14 \mu \mathrm{mol} / \mathrm{kg}$ and $-7 \mu \mathrm{mol} / \mathrm{kg}$ are suggested for TAlk values on A01 W and A09, respectively.

The caveats in the analysis and recommendations should be borne in mind. The purpose of the exercise was to create a mutually consistent data set of TAlk and DIC for the Atlantic Ocean based on data obtained on different cruises in the 1990s. This data set will be used to create gridded fields of DIC and TAlk for model validation and to determine basin-scale quantities such as anthropogenic $\mathrm{CO}_{2}$ inventories, carbonate saturation levels, and other relevant large-scale phenomena. The analysis of consistency is primarily focused on deep-water quantities with the assumption that these values are invariant on the decadal timescale. In the well-ventilated Atlantic Ocean, where large-scale natural changes manifest themselves through much of the water column, this is not always the best assumption. Moreover, in this analysis we assume that there are no systematic differences with depth. No comparisons in the upper water column were made, both because of seasonal variability in the upper ocean and because the anthropogenic perturbations are most noticeable there. 



\section{ACKNOWLEDGMENTS}

This report would not have been possible without the dedication of numerous field-going groups in the United States and abroad. The quality of the data is testament to their diligence. Rapid responses to inquiries by many of the investigators involved in the cruises greatly aided answering lingering questions. The organizers, ship's officers, crew, and scientists involved in the cruises as well those involved in the data reduction and interpretation are gratefully

acknowledged for their work.

The Atlantic synthesis effort was funded through a joint agreement of the U.S. Department of Energy (DOE) and the Global Carbon Cycle (GCC) Program of the Office of Global Programs (OGP) of the National Oceanic and Atmospheric Administration (NOAA). The funded investigators in the proposal, Synthesis and Interpretation of the NOAA/DOE Global $\mathrm{CO}_{2}$ Survey Data, are John Bullister, Richard Feely, Robert Key, Alexander Kozyr, Kitack Lee, Frank Millero, Tsung-Hung Peng, Christopher Sabine, and Rik Wanninkhof. We appreciate the efforts and enthusiasm of Dr. Lisa Dilling, program manager of the OGP/GCC program in coordinating the effort.

We wish to thank Walter Koncinski for editorial assistance and T.J. Blasing for his critical review of this document. 



\section{REFERENCES}

Byrne, R. H., and J. A. Breland. 1989. High precision multiwavelength $\mathrm{pH}$ determinations in seawater using cresol red. Deep-Sea Res 36: 803-10.

Chipman, D. W., J. Marra, and T. Takahashi. 1993. Primary production at $47^{\circ} \mathrm{N}$ and $20^{\circ} \mathrm{W}$ in the North Atlantic Ocean: A comparison between the ${ }^{14} \mathrm{C}$ incubation method and mixed layer carbon budget observations. Deep-Sea Res II 40: 151-69.

DelValls, T. A., and A. G. Dickson. 1998. The pH of buffers based on 2-amino-2-hydroxymethyl1,3-propanediol ("tris") in synthetic seawater. Deep-Sea Res. I 45: 1541-54.

Dickson, A. G., J. D. Afghan, and G. C. Anderson. Reference materials for oceanic $\mathrm{CO}_{2}$ analysis: A method for the certification of total alkalinity. Marine Chemistry (accepted Oct, 2002).

Dickson, A. G., G. C. Anderson, and J. D. Afghan. Reference materials for oceanic $\mathrm{CO}_{2}$ analysis: Preparation, distribution and use. Accreditation and Quality Assurance (submitted 2002).

Dickson, A. G., and F. J. Millero. 1987. A comparison of the equilibrium constants for the dissociation of carbonic acid in seawater media. Deep-Sea Res. 34: 1733-43.

DOE (U.S. Department of Energy). 1994. Handbook of methods for the analysis of the various parameters of the carbon dioxide system in sea water. Version 2. ORNL/CDIAC-74. A. G. Dickson, and C. Goyet (eds.), Carbon Dioxide Information Analysis Center, Oak Ridge National Laboratory, Oak Ridge, Tenn.

Feely, R. A., M. F. Lamb, D. J. Greeley, and R. Wanninkhof. 1999. Comparison of the carbon system parameters at the Global $\mathrm{CO}_{2}$ Survey crossover locations in the North and South Pacific Ocean, 1990-1996. ORNL/CDIAC-115. Carbon Dioxide Information Analysis Center, Oak Ridge National Laboratory, Oak Ridge, Tenn.

Gordon, L. I., C. Mordy, J. Wilson, and A. A. Ross. 1998. A study of discrepancies in observed nutrient concentrations at WHP Pacific line intersections: An accuracy estimate. pp. 24-29. In Ocean Circulation and Climate, Proceedings of the 1998 Conference of the World Ocean Circulation Experiment (WOCE), May 24-29, 1998, Halifax, Nova Scotia, Canada.

Houghton, J. T., L. G. Meira Filho, J. Bruce, H. Lee, B. A. Callander, E. Haites, E. Harris, and K. Maskell. 1995. Climate Change 1994: Radiative forcing of climate change and an evaluation of the IPCC IS92 Emission Scenarios. Cambridge University Press, Cambridge, England.

Houghton, J. T., Y. Ding, D. J. Griggs, M. Noguer, P. J. v. d. Linden, and D. Xiaosu. 2001. Climate Change 2001: The Scientific Basis: Contribution of Working Group I to the Third Assessment Report of the Intergovernmental Panel on Climate Change. Cambridge University Press, New York.

Johnson, K. M., K. D. Wills, D. B. Butler, W. K. Johnson, and C. S. Wong. 1993. Coulometric total carbon dioxide analysis for marine studies: maximizing the performance of an automated continuous gas extraction system and coulometric detector. Mar. Chem. 44: 16789.

Johnson, K. M., A. G. Dickson, G. Eischeid, C. Goyet, P. Guenther, R. M. Key, F. J. Millero, D. Purkerson, C. L. Sabine, R. G. Schottle, D. W. R. Wallace, R. J. Wilke, and C. D. Winn. 1998. Coulometric total carbon dioxide analysis for marine studies: Assessment of the quality 
of total inorganic carbon measurements made during the U.S. Indian Ocean $\mathrm{CO}_{2}$ survey, 1994-1996. Mar. Chem. 63: 21-37.

Key, R.M. 1999. Calibration of JGOFS/WOCE/OACES Carbon Measurements in the North Pacific Ocean. Ocean Tracers Laboratory Technical Report 99-3. Princeton University, Princeton, N.J.

Key, R.M. 2000. Calibration of JGOFS/WOCE/OACES Carbon Measurements in the North Pacific Ocean. Addendum to OTL Tech. Report 99-3. Ocean Tracers Laboratory Technical Report 99-3. Princeton University, Princeton, N.J.

Lamb, M. F., C. L. Sabine, R. A. Feely, R. Wanninkhof, R. M. Key, G. C. Johnson, F. J. Millero, K. Lee, T.-H. Peng, A. Kozyr, J. L. Bullister, D. Greeley, R. H. Byrne, D. W. Chipman, A. G. Dickson, C. Goyet, P. R. Guenther, M. Ishii, K. M. Johnson, C. D. Keeling, T. Ono, K. Shitashima, B. Tilbrook, T. Takahashi, D. W. R. Wallace, Y. W. Watanabe, C. Winn, and C. S. Wong. 2001. Consistency and synthesis of Pacific Ocean $\mathrm{CO}_{2}$ survey data. Deep Sea Res. II 49(1-3): 21-58.

Lee, K., F. J. Millero, R. H. Byrne, R. A. Feely, and R. Wanninkhof. 2000. The recommended dissociation constants of carbonic acid for use in seawater. Geophys. Res. Lett. 27: 229-32.

Lewis, E., D. W. R. Wallace, and L. J. Allison. 1998. Program developed for $\mathrm{CO}_{2}$ system calculations. ORNL/CDIAC-105. Carbon Dioxide Information Analysis Center, Oak Ridge National Laboratory, Oak Ridge, Tenn.

Mehrbach, C., C. H. Culberson, J. E. Hawley, and R. M. Pytkowicz. 1973. Measurement of the apparent dissociation constants of carbonic acid in seawater at atmospheric pressure. Limnology and Oceanography 18: 897-907.

McElligott, S., R. H. Byrne, K. Lee, R. Wanninkhof, F. J. Millero, and R. A. Feely. 1998. Discrete water column measurements of $\mathrm{CO}_{2}$ fugacity and $\mathrm{pH}$ in seawater: A comparison of direct measurements and thermodynamic calculations. Mar. Chem. 60, 63-73.

Millero, F. J., and A. Poisson. 1981. International one-atmosphere equation of state of seawater. Deep-Sea Research 28A: 625-29.

Millero, F. J., J.-Z. Zhang, K. Lee, and D. Campbell. 1993. Titration alkalinity of seawater. Mar. Chem. 44: 153-67.

Millero, F. J., A. G. Dickson, G. Eischeid, C. Goyet, P. Guenther, K. M. Johnson, R. M. Key, K. Lee, D. Purkerson, C. L. Sabine, R. G. Schottle, D. W. R. Wallace, E. Lewis, and C. D. Winn. 1998. Assessment of the quality of the shipboard measurements of total alkalinity on the WOCE Hydrographic Program Indian Ocean $\mathrm{CO}_{2}$ survey cruises 1994-1996. Mar. Chem. 63(1-2): 9-20.

Millero, F. M., D. Pierrot, K. Lee, R. Wanninkhof, R. Feely, C. L. Sabine, R. M. Key, and T. Takahashi. Dissociation constants for carbonic acid determined from field measurements. Deep-Sea Res. I (submitted).

Neill, C., K. M. Johnson, E. Lewis, and D. W. R. Wallace. 1997. Small volume, batch equilibration measurement of $f \mathrm{CO}_{2}$ in discrete water samples. Limnol. Oceanogr. 42: 1774-83.

Perez, F. F., and F. Fraga. 1987. A precise and rapid analytical procedure for alkalinity determination. Mar. Chem. 21: 169-82. 
Ríos, A. F., and F. F. Perez. 1999. Improvements in potentiometric determinations of the $\mathrm{CO}_{2}$ oceanic system using seawater substandards and $\mathrm{CO}_{2}$ reference materials. Ciencias Marinas 25: $31-49$.

Sabine, C. L., R. M. Key, K. M. Johnson, F. J. Millero, A. Poisson, J. L. Sarmiento, D. W. R. Wallace, and C. D. Winn. 1999. Anthropogenic $\mathrm{CO}_{2}$ inventory of the Indian Ocean. Global Biogeochem. Cycles 13: 179-98.

Saunders, P. M., and N. P. Fofonoff. 1976. Conversion of pressure to depth in the ocean. DeepSea Res. 23: 109-11.

Wanninkhof, R., and K. Thoning. 1993. Measurement of fugacity of $\mathrm{CO}_{2}$ in surface water using continuous and discrete sampling methods. Mar. Chem. 44 (2-4):189-205.

Weiss, R. F. 1974. Carbon dioxide in water and seawater: the solubility of a non-ideal gas. Mar. Chem. 2: 203-15.

WOCE. 1994. WOCE Operations Manual, Section 3.1: WOCE Hydrographic Programme. World Ocean Circulation Experiment, Woods Hole, Mass. 
